\title{
Effect of ozone treatment on the microstructure, chemical composition and sensory quality of apple fruits
}

\author{
Karina Juhnevica-Radenkova1, Vitalijs Radenkovs ${ }^{1}$, \\ Karlis Kundzins ${ }^{2}$ and Dalija Seglina ${ }^{1}$
}

\begin{abstract}
The aim of this study was to assess the effect of $\mathrm{O}_{3}$ treatment on the quality of different cultivars of apples (Malus domestica Borkh.). Apples were stored for six months at different concentrations of ozone. During the research, minor differences between ozone-treated and control fruits were found in terms of cell integrity and epicuticular wax structure. Ozone application for apple treatment could accelerate the natural ageing of the waxes found on the surface of apples, thereby reducing the thickness of the waxes. The rate of degradation for the epicuticular wax was found to be cultivar dependent. After six months of storage, the ozonation process prevented the decay of 'ledzenu', 'Auksis' and 'Belorusskoje Malinovoje' apple cultivars, but it accelerated damage in the 'Gita' apple cultivar. A positive impact of ozone during long-term storage was found regarding flesh firmness of 'ledzenu' apple cultivar samples subjected to $\mathrm{O}_{3}$ exposure at concentrations of $0.8 \mathrm{ppm}$ and $3.0 \mathrm{ppm}$. In other cultivars of apples, significant differences between ozonation and cold storage (control) were not found. In general, ozone treatment has a potential to be applied in order to maintain the sensory quality and biologically active compound level in apples during six-month storage; however, the degree of effectiveness depends both on the cultivar and on the concentration of ozone.
\end{abstract}

\section{Keywords}

Apple treatment, microstructure, postharvest storage, sensory evaluation, quality

Date received: 2 January 2017; accepted: 2 November 2018

\section{INTRODUCTION}

Apple (Malus domestica Borkh.) is a popular temperate fruit, consumed both fresh and processed and ranked third in global fruit production at 80.8 million tonnes in 2013 (FAOSTAT, 2013). Global production is centred on the high-value fresh market, which requires maintaining fruit quality during long-term storage and shipping (Greene et al., 2014; McCluskey et al., 2007).

Ozone $\left(\mathrm{O}_{3}\right)$ is widely used as an anti-microbial agent to inactivate bacteria, fungi, viruses and protozoa, allowing water in the food industry to be disinfected and wastewater to be reused, as well as controlling the alkalinity and $\mathrm{pH}$ of shrimp pond water (Kim et al., 1999). Ozone has been approved for use in food by the United States Food and Drug Administration (2018) and is thought to reduce decay in some fruits and vegetables, although results have been inconsistent (Forney, 2003). Both advantages (Harding, 1968; Jin et al., 1989; Liew and Prange, 1994; Palou et al., 2002; Palou et al., 2003; Pinilla et al., 1996; Sarig et al., 1996; Skog and Chu, 2001) and disadvantages (Pérez et al., 1999) of ozone in air

\footnotetext{
${ }^{1}$ Institute of Horticulture, Latvia University of Life Sciences and Technologies, Dobele, Latvia

${ }^{2}$ Institute of Solid State Physics, University of Latvia, Riga, Latvia

Corresponding author:

Vitalijs Radenkovs, Institute of Horticulture, Latvia University of Life Sciences and Technologies, Graudu Street 1, Dobele LV-3701, Latvia.

Email: vitalijs.radenkovs@Ivai.Iv
} 
use in fruit and vegetable storage rooms have been reported. It has been reported by Forney (2003) that the degree of injury depends on $\mathrm{O}_{3}$ exposure time, concentration and apple cultivar. For instance, Smilanick (2003) noted that no fruits were wounded by daily exposure during five months at $1.95 \mathrm{ppm}$. However, the aroma of all cultivars tested except Golden Delicious was aggravated by $3.25 \mathrm{ppm}$ of ozone. Furthermore, the author concluded that no impairment was caused by $1.95 \mathrm{ppm}$ on any variety tested. In terms of structural changes, it is obvious that some cultivars of apples promptly becoming sticky and covered by varnish may be observed. In terms of physiological properties, no differences were found between treated and untreated fruit (Smilanick, 2003). Changes in the fruit surface gloss suggested probable modifications to the light reflectance characteristics which could be caused by either a loss of cuticular and/or ultra-structural changes in the crystalline structure of the surface wax. Any modification in the fruit surface could also contribute to a reduction in the adherence of the pathogen, thereby reducing colonisation (Charles et al., 2008).

Due to its strong oxidizing activity, ozone may cause physiological damages to fruits and vegetables (Horvath et al., 1985). Bananas treated with ozone developed black spots after eight days of exposure to 25 to $30 \mathrm{ppm}$ of gaseous ozone. Carrots exposed to ozone gas during storage had a lighter, less intense colour than untreated carrots (Liew and Prange, 1994). A study on kiwi fruit showed that sugar reduction was lower in cold storage with ozone treatment than in cold storage between 15 and 29 weeks of storage, and that cold storage better conserved organic acids (citric, quinic and malic acids) than in ozone-treated fruits at 29 weeks (Barboni et al., 2010). A study on tomatoes showed that short-term gaseous ozone treatment $(10 \mu \mathrm{L} / \mathrm{L} ; 10 \mathrm{~min})$ increased the total phenolics content immediately after treatment and after six days of storage at $20^{\circ} \mathrm{C}$ (Rodoni et al., 2009). Onions, citrus fruit, russet potatoes, cantaloupes, waxed apples and kiwi fruit were unharmed when examined one week after treatment, while stone fruit, mushrooms, bananas, leafy vegetables of many kinds, snow peas, mangos, broccoli, Brussels sprouts and un-waxed apples and pears were severely harmed (Smilanick, 2003). Skog and Chu (2001) showed that ozone could effectively prevent ethylene accumulation in apples and pears in storage rooms at a concentration of $0.4 \mathrm{ppm}$. Mushrooms, apples, pears, broccoli and cucumbers tolerated this low concentration without harm. On the whole, the effect of ozone on fruit quality is inconsistent in different fruit species, and the ozone concentration, application method and period seem to be very important in optimising the treatment effect.
The aim of this study was to assess the effect of $\mathrm{O}_{3}$ treatment on the quality of different cultivar of apples (Malus domestica Borkh.).

\section{MATERIAL AND METHODS}

The research was carried out between 2015 and 2016 at the Experimental Processing Department of the Latvia State Institute of Fruit-Growing (currently, Institute of Horticulture, Latvia University of Life Sciences and Technologies) in Dobele and at the Institute of Solid State Physics, University of Latvia.

The following apple cultivars were chosen for the experiment - autumn cultivars: 'Auksis' and 'Gita' and winter cultivars: 'Iedzenu', 'Belorusskoje Malinovoje'. All apple trees were grafted on the rootstock B9 and grown under the same conditions in the orchard run in an integrated system. Shortly after harvesting, apples were air-cooled for $24 \mathrm{~h}$ in a cooling chamber at $4{ }^{\circ} \mathrm{C} \pm 0.5^{\circ} \mathrm{C}$. Forty fruits (approximately $6 \mathrm{~kg}$ ) were sampled per cultivar $/$ per treatment/storage technology. Samples were then placed in polypropylene boxes with perforated walls. The cooled down apples were divided into three groups for post-harvest storage: (1) cold storage - control storage under traditional conditions at air temperature $+2 \pm 1{ }^{\circ} \mathrm{C}$ and relative air humidity of $85 \%$; (2) cold storage + ozone treatment at a concentration of $0.8 \mathrm{ppm}$; (3) cold storage + ozone treatment at a concentration of $3.0 \mathrm{ppm}$. Analyses were carried out after long-term apple storage (six months) and after an additional five days of shelf life. In the research, apple treatment with an ozone concentration of $0.8 \mathrm{ppm} \quad(150 \mathrm{mg} / \mathrm{h}, \quad \mathrm{FM}-300$ ozone generator, Baifeng Ozone Technical Co., Ltd, Guangzhou, China) and 3 ppm $(1000 \mathrm{mg} / \mathrm{h}, \mathrm{L}-1000$ ozone generator, Baifeng Ozone Technical Co., Ltd, Guangzhou, China) was conducted in a $1 \mathrm{~m}^{3}$ cold storage room set to maintain a room concentration of ozone. This concentration of $\mathrm{O}_{3}$ was selected based on the previous small scale in vitro experiments as well as according to the manufacturer's recommendations. Control apple fruits were stored under the same environmental conditions in conventional atmosphere (cold storage/control).

Ten fruits were used individually for the analysis of flesh firmness $(\mathrm{N})$, soluble solids content $\left({ }^{\circ}\right.$ Brix), and titratable acidity $(\%)$. Fresh weight loss was determined by the scaling method provided by Billiard (1999). Flesh firmness was measured on two opposite sides of each apple without skin using a digital penetrometer (model TR 53205, Italy) which was equipped with $11 \mathrm{~mm}$ diameter probe; peak destructive force was expressed in Newtons $(\mathrm{N})$. Titratable acidity was determined using standard method (LVS EN 12147:2001) and quantified by titration of $1 \mathrm{ml}$ of juice (automatic titration DL 21, Mettler Toledo, Swiss) with $0.1 \mathrm{M}$ 
$\mathrm{NaOH}$ to a $\mathrm{pH}$ of 8.1. Expended amount of $\mathrm{NaOH}$ was expressed in percentage of malic acid. The soluble solid content was determined using standard method (LVS EN 12143:2001). Ten fruits were selected and ground with the hand blender 'Bamix ${ }^{\mathbb{R}}$, (Switzerland, model SwissLine, Liechtensteinn) into a puree. The content of soluble solids (in ${ }^{\circ}$ Brix) was determined using a digital electronic refractometer (type Pal-1, Tokyo, Japan).

Apple deterioration was determined using a method provided by Juhnevica et al. (2013). Apple skin colour was measured by using a ColorTec-PCM Plus $30 \mathrm{~mm}$ Benchtop colorimeter (Clinton, New York). The values for $L^{*}(+=$ lighter, $-=$ darker $), a^{*} \quad(+=$ redder, $-=$ greener $)$, and $b^{*}(+=$ yellower, $-=$ bluer $)$ were recorded to evaluate the colour changes of apples after six months' storage (Biller et al., 2007).

SEM analysis was performed by using a Tescan Mira/ LMU scanning electron microscope operating in low vacuum mode $\left(\mathrm{PH}_{2} \mathrm{O}=0.1-1.0\right.$ torr $)$ using a large field detector (LFD) and in environmental mode (ESEM, $\mathrm{PH}_{2} \mathrm{O}=1.0-4.8$ torr) using a gaseous secondary electron detector. Specimens approximately $1 \mathrm{~mm}$ thick were cut from apple samples. For the low vacuum analysis, they were mounted onto SEM stubs by means of double sided adhesive carbon discs and observed at 10-20 kV acceleration voltage. For the ESEM analysis, specimens were placed on the cooling stage, setting the temperature to $1{ }^{\circ} \mathrm{C}$ and observing at $20-30 \mathrm{kV}$ acceleration voltage.

The total phenolic content was determined spectrophotometrically using the Folin-Ciocalteu method (Singleton et al., 1999). Determination of the vitamin C content was performed using standard method (LVS EN 14130:2003). Tannin content was determined spectrophotometrically (Paaver et al., 2010). Antioxidant activity of extracts was evaluated spectrophotometrically (Brand-Williams et al., 1995).

Fifteen well-trained panellists (5 men and 10 women), aged between 25 and 50, participated in the current study. The sensory attributes of apples were evaluated using: Hedonic scale evaluation by the standard method 'ISO 4121:2003 - Sensory analysis Guidelines for the use of quantitative response scales'. All samples were coded with random three-digit numbers. The panellists were provided with five slices of apples for every experimental sample and asked to score different sensory attributes. To avoid unwanted browning, apples were cut just before being served and placed on each serving tray in a randomized order. To evaluate the overall acceptability of the apple (external quality), slices were served together with a whole uncut apple sample. To evaluate sensory attributes such as appearance, aroma, taste, maturity stage, acidity, sweetness and juiciness for all apple samples, assessment was carried out using five-point Hedonic scale with the following ratings: 1 - 'dislike very much', 2 - 'dislike', 3 - 'neither like or dislike', 4 - 'like', 5 - 'like very much'.

Data analysis was carried out using the General Linear Model functions in the IBM ${ }^{\circledR}$ SPSS $^{\circledR}$ Statistics programme 20.0 (SPSS Inc., Chicago, IL). The obtained data were analysed using descriptive statistics. Significant differences determined using UNIANOVA, by 'Least Significant Difference' (LSD) criteria. The significance of differences was determined at $p<0.05$. Mean and standard deviation values were calculated for all parameters. In order to compare sensory data obtained from Line scale evaluation, as well as to classify the samples in terms of chemical composition, the results were processed by PanelCheck V1.4.2, programmed by Oliver Tomic and Henning Risvik software using principal component analysis (PCA) (Næs et al., 2010). PCA provides a representation of the dataset in a small number of dimensions called principal components, which explain the majority of the variance of the dataset. In the current research, PCA represents the similarities and differences among the samples, as well as their relationship with the evaluated sensory attributes. For instance, if the average score of a particular attribute is equal to another score, points are located on the plot close to each other and enclosed in an ellipse. Furthermore, if a particular attribute strongly correlates with the particular sample, its location is near the sample and enclosed in an ellipse (Piqueras-Fiszman et al., 2015).

\section{RESULTS AND DISCUSSION}

Little is known about the effect of $\mathrm{O}_{3}$ treatment on apples during post-harvest long-term storage (Yaseen et al., 2015); therefore, it is important to evaluate the quality of apples that have been exposed to different concentrations of $\mathrm{O}_{3}$. Epicuticular waxes are of interest because they are involved in preventing excessive water loss, protecting the living tissue of the plant from external attack including UV light and influencing the uptake of chemicals such as pesticides (Kochar, 2015). As can be seen (Figures 1 to 4), fresh apple shows nonuniform epicuticular covering the cells with clearly expressed epicuticular crystals. In turn, after apple treatment with $\mathrm{O}_{3}$, there was a noticeable decrease in the deposition and morphology of epicuticular wax crystals on the apple surface (Figures 1, 3 and 4). After apple treatment with $\mathrm{O}_{3}$ at concentrations of $0.8 \mathrm{ppm}$ and $3.0 \mathrm{ppm}$, the surface of 'Iedzenu', 'Belorusskoje Malinovoje' and 'Gita' apples became smoother and more homogenous with no pronounced epicuticular peaks of wax crystals. Due to the lack of scientific literature towards structural changes of apples after $\mathrm{O}_{3}$ exposure, a direct comparison is not possible. To the best of our knowledge and on the basis of some 


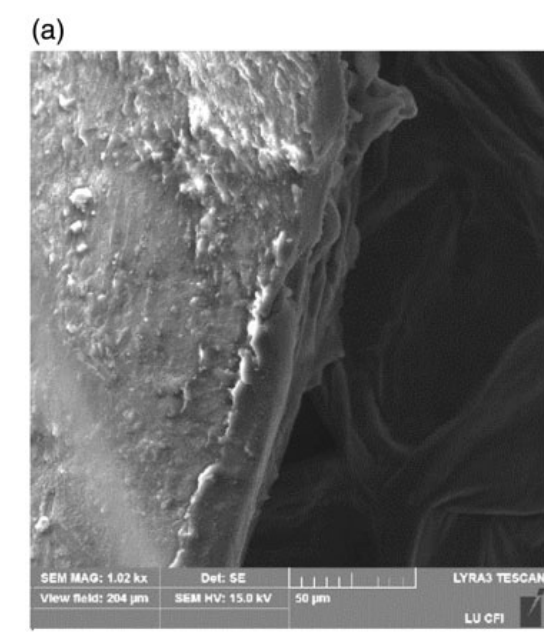

(b)

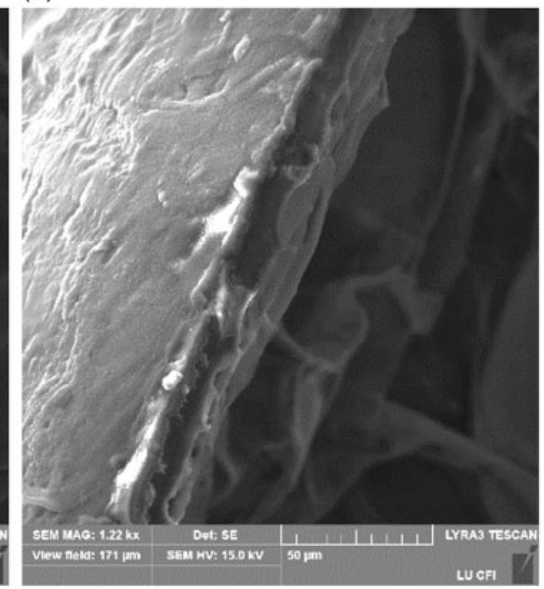

(c)

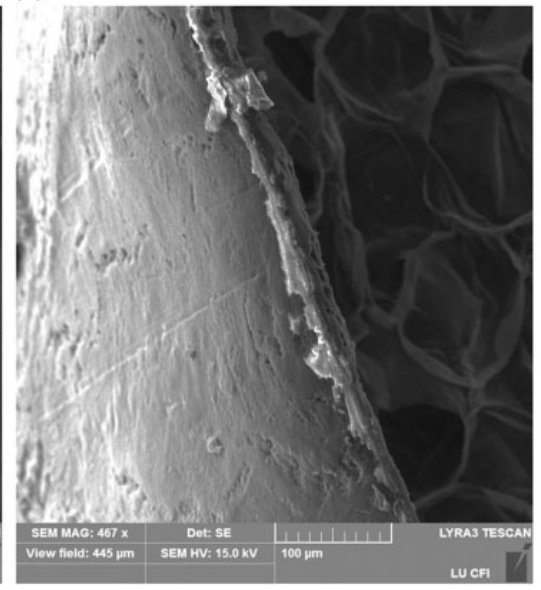

Figure 1. Structure of the epidermal layer with epicuticular crystals of cultivar 'ledzenu' apples, (a) cold storage (control), (b) ozone concentration $0.8 \mathrm{ppm}$, (c) ozone concentration $3.0 \mathrm{ppm}$.

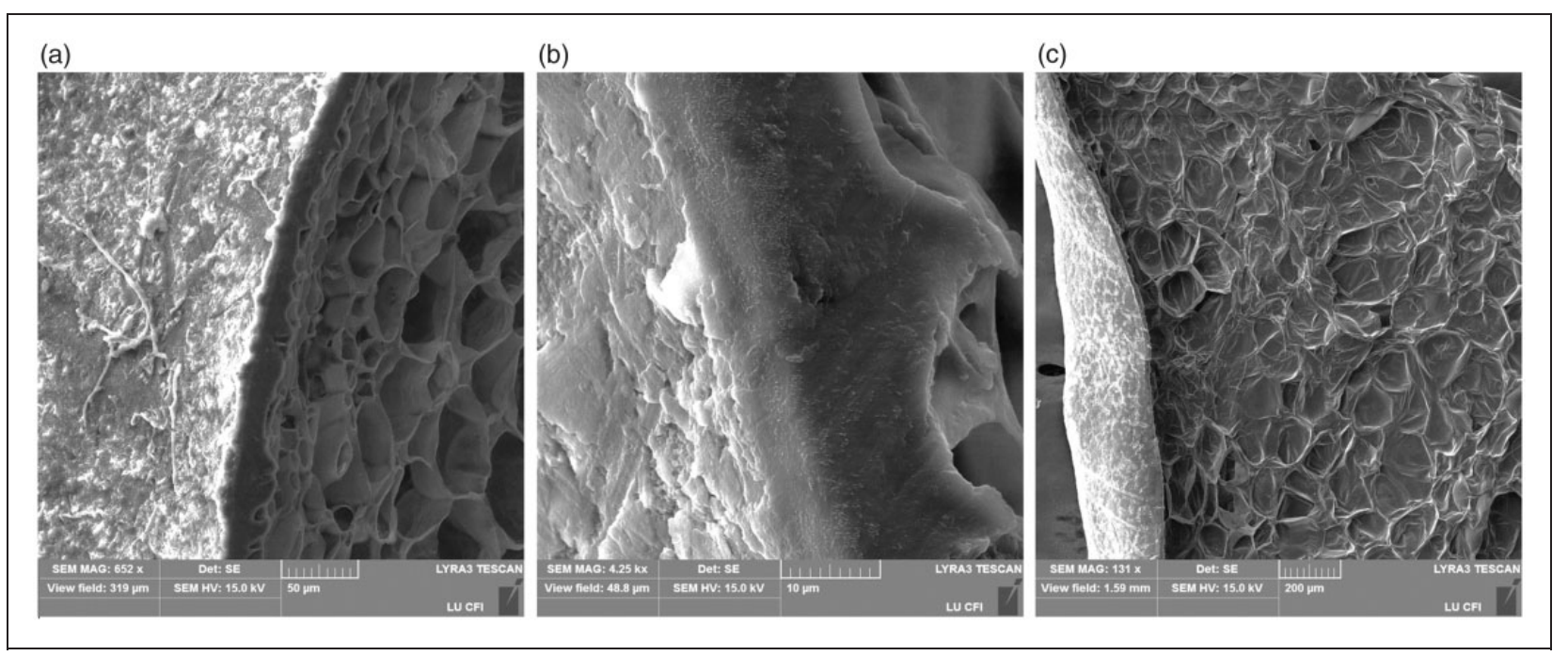

Figure 2. Structure of the epidermal layer with epicuticular crystals of cultivar 'Auksis' apples, (a) cold storage (control), (b) ozone concentration $0.8 \mathrm{ppm}$, (c) ozone concentration $3.0 \mathrm{ppm}$.

papers Percy et al. (2009) and Kochar (2015) related to exposure to different concentrations of $\mathrm{O}_{3}$, one can conclude that the composition of plant epicuticular layers can be affected and changed by chemicals, particularly by secondary pollutant - ozone. Ozonizing of fruits during storage did not show any positive effect on the surface of the apple. Conversely, ozone application for apple treatment could accelerate the natural ageing of the waxes found on the surface of apples, thereby reducing the thickness of the waxes and facilitating a greater rate of transpiration.

Apple structure is a critical quality feature for the consumer, as it is strictly correlated to the firmness of the fruit. The structure of fruits is determined by physical characteristics that arise from structural organization of cells and tissues. Cell integrity strongly impacts structural quality (Laurienzo et al., 2013). The control apple samples (Figures 5(a), 6(a), 7(a) and 8(a)) had a regular structure, while cells of cultivar 'Belorusskoje Malinovoje' and 'Auksis' apples those exposed to ozone treatment of concentrations of $0.8 \mathrm{ppm}$ and $3.0 \mathrm{ppm}$ collapsed with non-uniform homogeneity (Figure 7(b) and (c)). Severe shrinkage is due to the thickness of the skin typical for these cultivars. It was observed that such cultivars have very thin skin and therefore higher permeability of gaseous ozone 


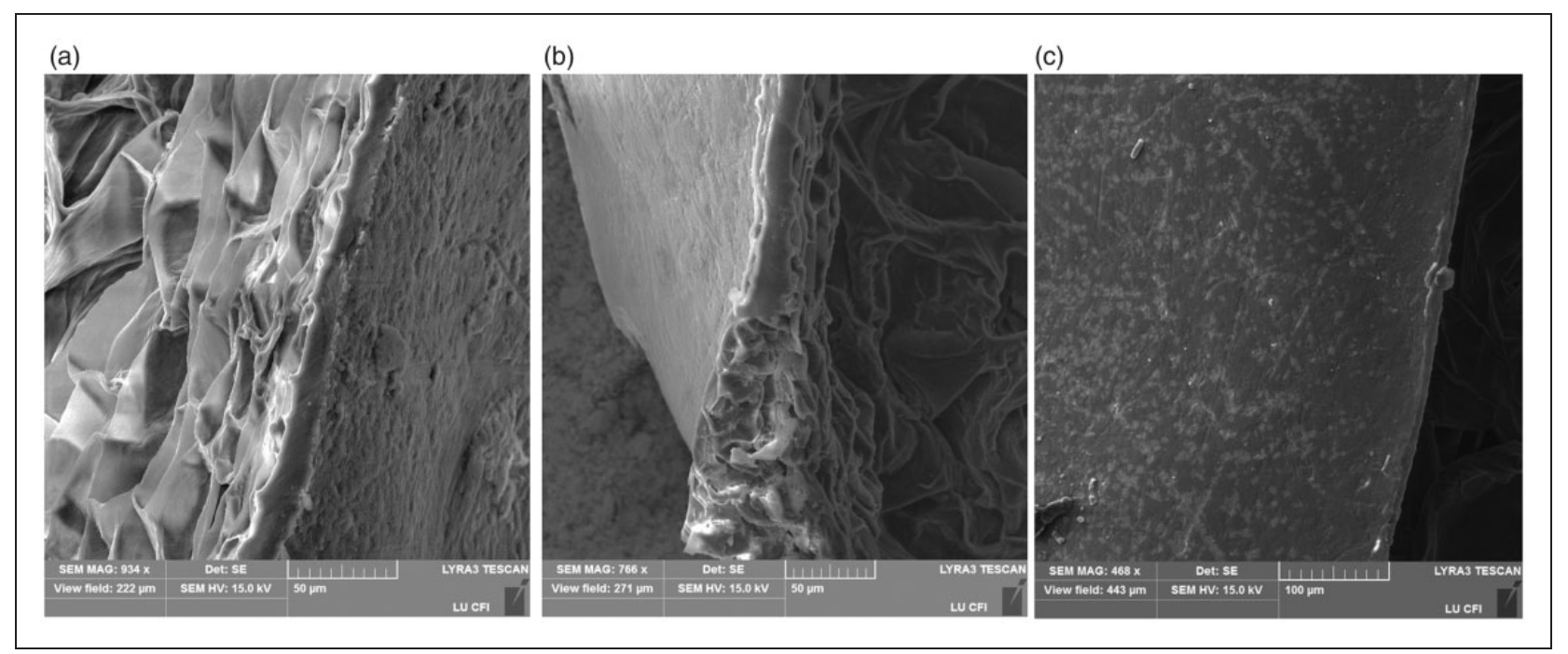

Figure 3. Structure of the epidermal layer with epicuticular crystals of cultivar 'Belorusskoje Malinovoje' apples, (a) cold storage (control), (b) ozone concentration $0.8 \mathrm{ppm}$, (c) ozone concentration $3.0 \mathrm{ppm}$.

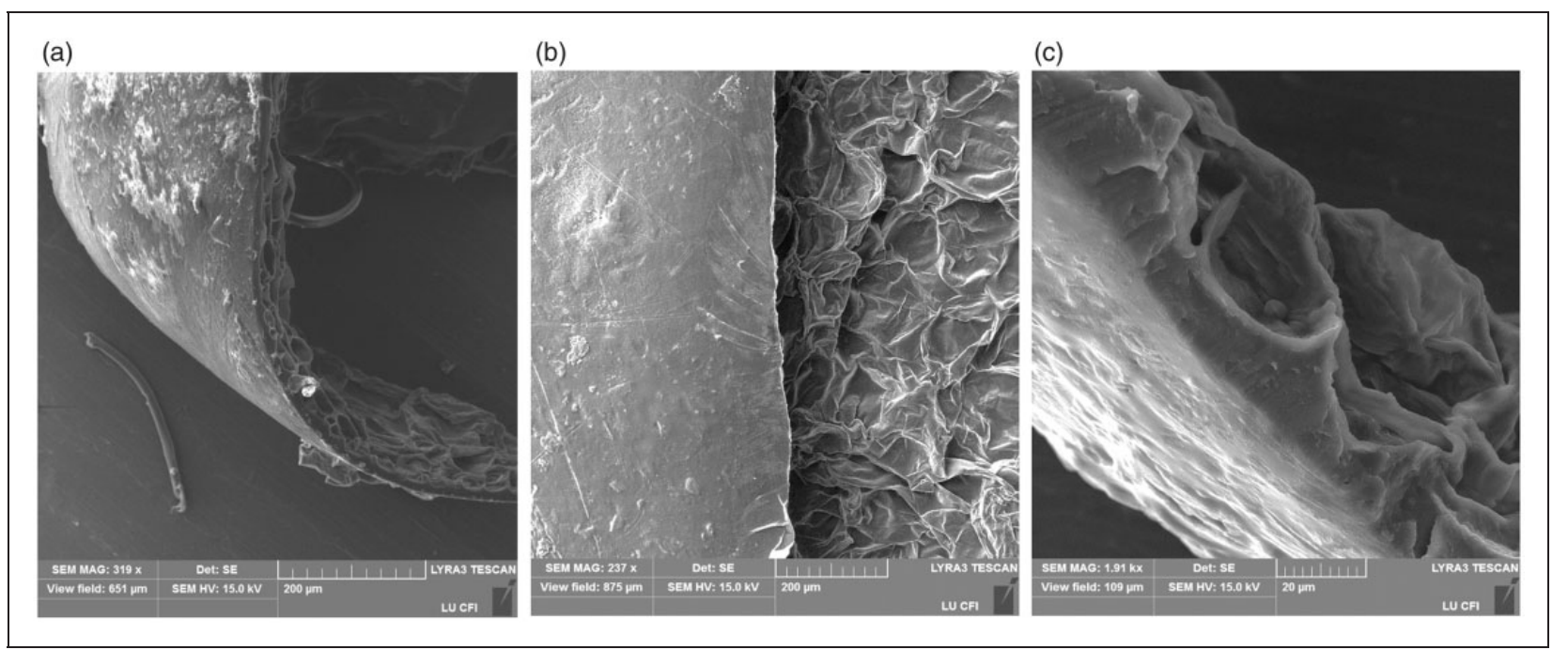

Figure 4. Structure of the epidermal layer with epicuticular crystals of cultivar 'Gita' apples, (a) cold storage (control), (b) ozone concentration $0.8 \mathrm{ppm}$, (c) ozone concentration $3.0 \mathrm{ppm}$.

compared to other fruit. Authors from Latvia (Radenkovs and Juhnevica-Radenkova, 2018) found significantly greater weight loss and firmness decline in a cultivar of 'Belorusskoje Malinovoje' apples than in other fruit. Moreover, membrane cracks and fibre development (Figure 6(b) and (c)) can be observed in the cultivar 'Auksis' apples, indicating that ozone treatment causes cells membrane damage. However, the degree of damage is cultivar dependent.

In general, it should be noted that minor differences concerning cell integrity were found between ozonetreated and control fruits. The vast majority of the changes were found towards epicuticular wax structure; in presence of ozone epicuticular, the surface became stickier, thinner and varnish-like.

A number of researchers have recommended the use of ozonation to reduce fruit decay and extend the storage period (Harding 1968; Jin et al., 1989; Liew and Prange, 1994; Palou et al., 2002; Palou et al., 2003; Pinilla et al., 1996; Sarig et al., 1996; Skog and Chu, 2001) of fruits. Some papers have shown that ozone has little or no effect on fruit decay (Pérez et al., 1999), or fruits decayed even more in the presence of ozone than in the normal atmosphere. 


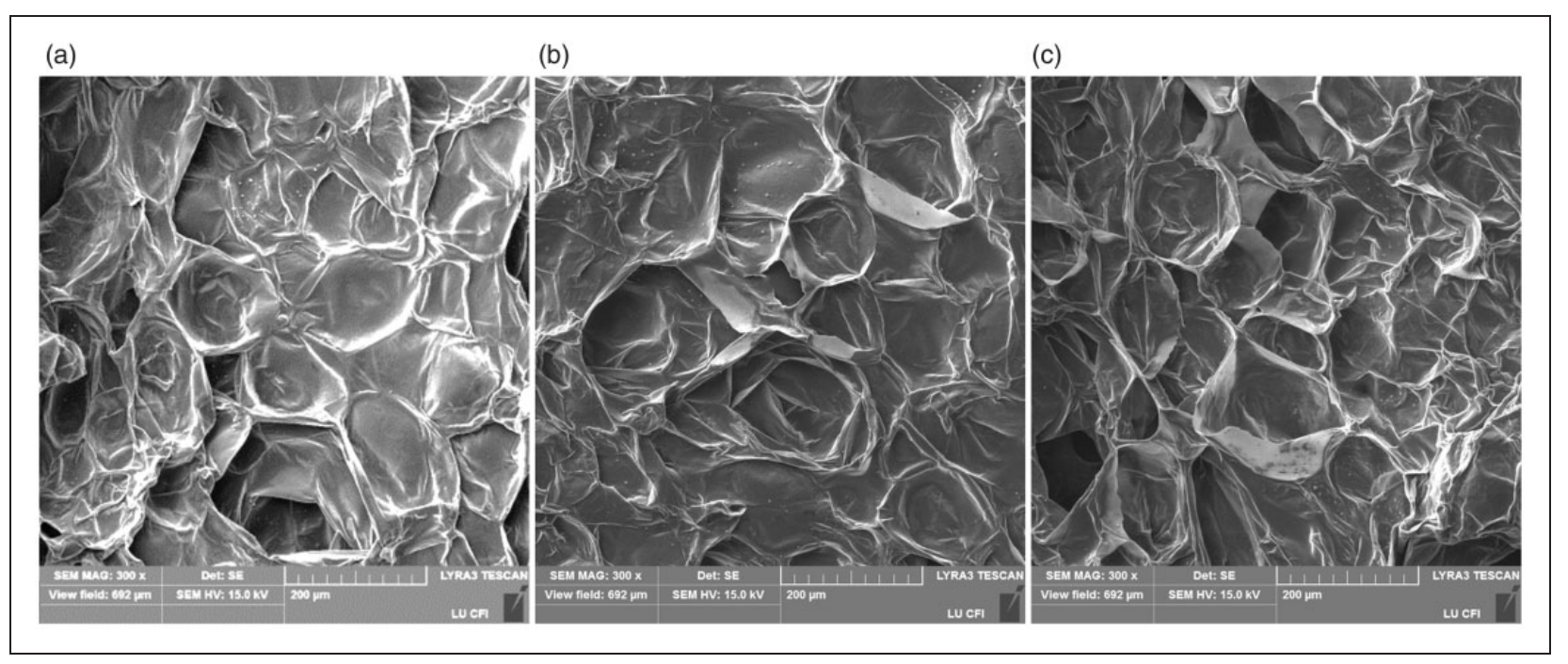

Figure 5. Cell structure of cultivar 'ledzenu' apples, (a) cold storage (control), (b) ozone concentration $0.8 \mathrm{ppm}$, (c) ozone concentration $3.0 \mathrm{ppm}$.

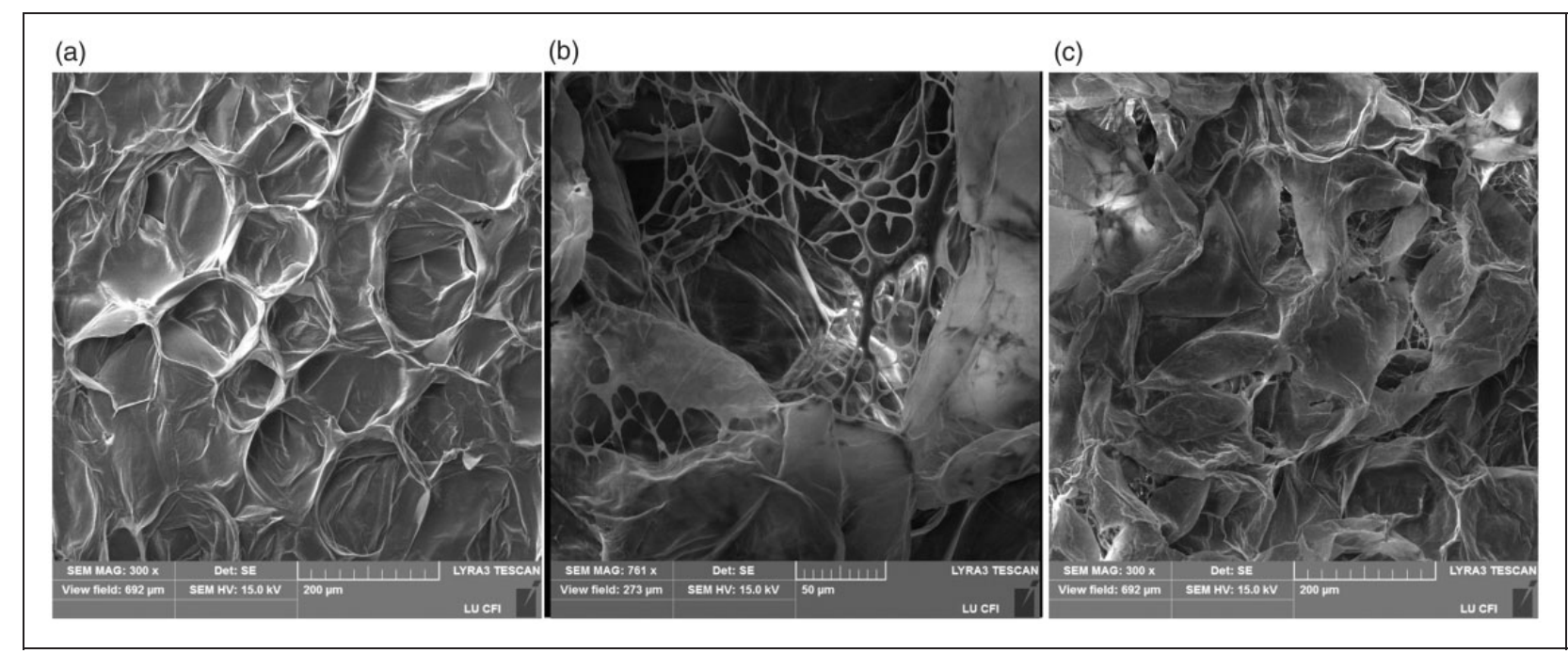

Figure 6. Cell structure of cultivar 'Auksis' apples, (a) cold storage (control), (b) ozone concentration 0.8 ppm, (c) ozone concentration $3.0 \mathrm{ppm}$.

Data depicted in Table 1 show that after six months of apple storage, severity of spoilage fluctuated in a range from $3.57 \%$ to $26.67 \%$ (control samples), from $0.00 \%$ to $30.61 \%$ (ozone treated at $0.8 \mathrm{ppm}$ ) and from $0.00 \%$ to $27.08 \%$ (ozone treated at $3.0 \mathrm{ppm}$ ). The amount of damaged apples after shelf life was from $0.00 \%$ to $2.23 \%$ (control samples), from $1.09 \%$ to $2.04 \%$ (ozone treated at $0.8 \mathrm{ppm}$ ) and from $1.51 \%$ to $5.83 \%$ (ozone treated at $3.0 \mathrm{ppm}$ ). The occurrence of spoilage after long-term storage was associated with physiological disorders (data not shown), particularly decay caused by superficial and soft scald. Deterioration in the quality of apple during shelf life was related with pronounced softening of fruits. In the paper presented by Skog and Chu (2001), it was shown that ozone could effectively prevent ethylene accumulation, thereby reducing the softening in apple and pear in storage rooms at a concentration of $0.4 \mathrm{ppm}$. Our results partially coincide with the abovementioned statement. In general, it should be noted that the application of ozone at concentrations of $0.8 \mathrm{ppm}$ and $3.0 \mathrm{ppm}$ could be used for the preservation of apple fruits during postharvest storage. The ozonation process prevented decay of 'Iedzenu', 'Auksis' and 'Belorusskoje Malinovoje' apple cultivars, but it accelerated damage in the 'Gita' cultivar.

Postharvest softening of apple is a serious problem for many growers, including Latvia. Recently, 


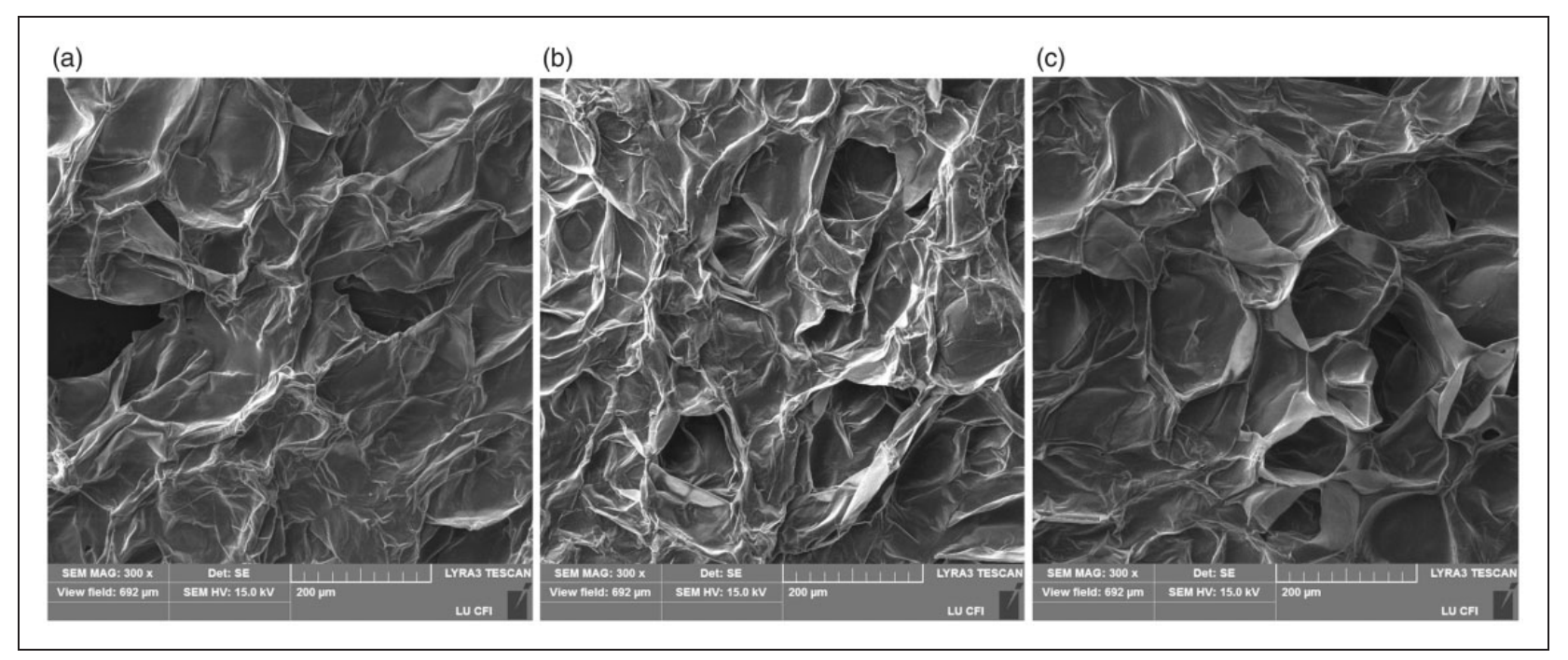

Figure 7. Cell structure of cultivar 'Belorusskoje Malinovoje' apples, (a) cold storage (control), (b) ozone concentration $0.8 \mathrm{ppm}$, (c) ozone concentration $3.0 \mathrm{ppm}$.

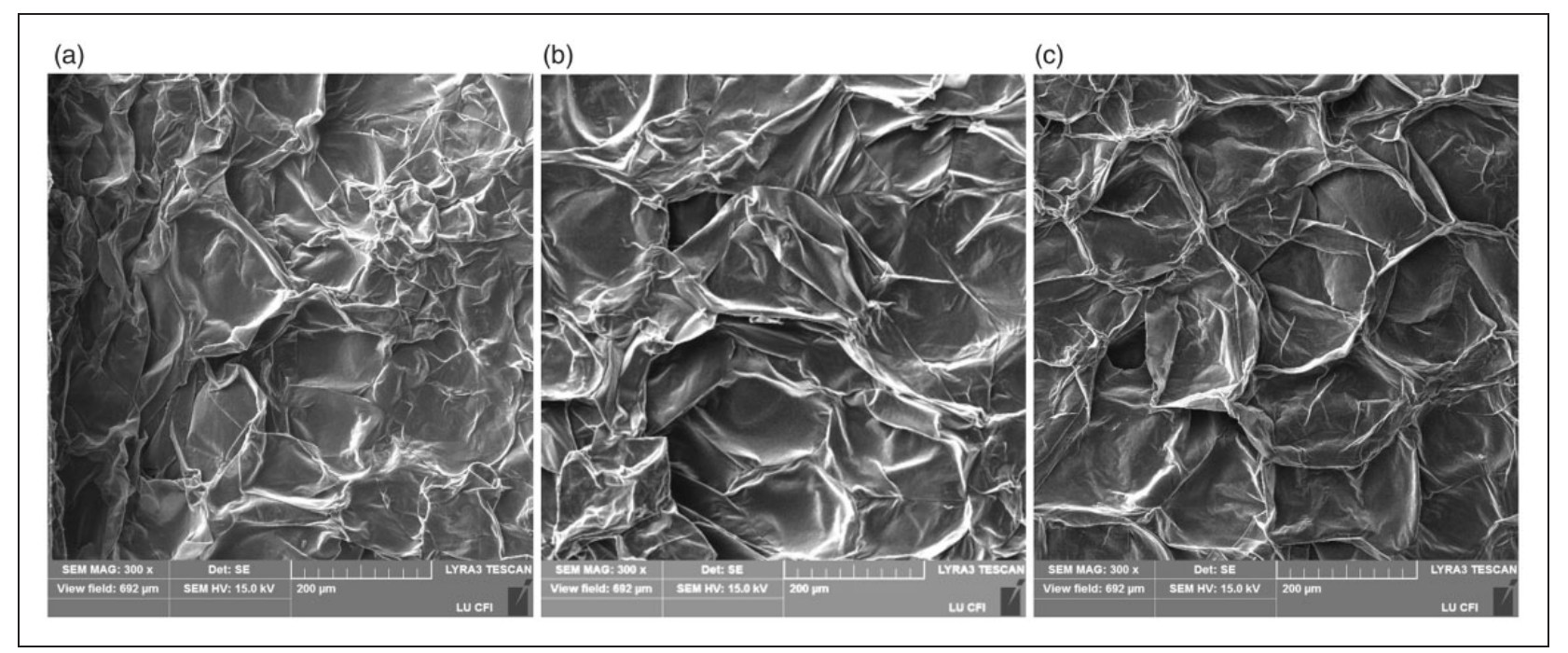

Figure 8. Cell structure of cultivar 'Gita' apples, (a) cold storage (control), (b) ozone concentration 0.8 ppm, (c) ozone concentration $3.0 \mathrm{ppm}$.

considerable research has been carried out aimed to identify the biological causes of softening, so that this process can be managed or regulated more effectively. Softening is generally considered an undesirable ripening process in apple fruit, as firmer apples tend to be juicier, crisper, crunchier and less mealy than softer fruit (Conforti and Totty, 2007). Results showed that after six months of apple storage (Table 2), weight loss was significantly higher in 'Gita' apples $(29.41 \%)$ treated with ozone at a concentration of $3.0 \mathrm{ppm}$, while for other cultivars differences between treatments were less pronounced. During the shelf life, the same trend is observed, where highest weight loss noted in ozone treated $(0.8 \mathrm{ppm}$ and $3.0 \mathrm{ppm})$ 'Gita' apples $(0.08 \%$ and $0.10 \%$, respectively) and $3.0 \mathrm{ppm}$ treated 'Iedzenu' apples (0.24\%). Forney et al. (2003) and Palou et al. (2002) found an increase in peaches and broccoli weight loss, respectively, and assigned this effect to cuticle degradation. Moreover, a strong correlation has been found between fruit weight loss and thickness of a cuticular layer (Veravrbeke et al., 2003). Taking into consideration weight loss of ozone-treated samples and structure of apple samples presented previously, the line of interrelation was not found. Our observation does not coincide with abovementioned researchers. 
Table 1. Number of damaged apples stored under different conditions, \%.

\begin{tabular}{|c|c|c|c|}
\hline \multirow[b]{2}{*}{ Cultivar } & \multirow[b]{2}{*}{$\begin{array}{l}\text { Ozone } \\
\text { concentration }\end{array}$} & \multicolumn{2}{|c|}{ Storage time } \\
\hline & & $\begin{array}{l}\text { After six } \\
\text { months } \\
\text { of storage }\end{array}$ & $\begin{array}{l}\text { After shelf } \\
\text { life of } \\
\text { five days }\end{array}$ \\
\hline \multirow[t]{3}{*}{ ‘ledzenu’ } & Control & $21.62 a$ & $1.80 \mathrm{~b}$ \\
\hline & $0.8 \mathrm{ppm}$ & $14.29 b$ & $1.98 b$ \\
\hline & $3.0 \mathrm{ppm}$ & $13.16 \mathrm{c}$ & $5.83 a$ \\
\hline \multirow[t]{3}{*}{ 'Auksis' } & Control & $5.97 a$ & $1.81 \mathrm{a}$ \\
\hline & $0.8 \mathrm{ppm}$ & $0.00 c$ & $1.09 a$ \\
\hline & 3.0 ppm & $3.13 b$ & $2.88 a$ \\
\hline \multirow{3}{*}{$\begin{array}{l}\text { 'Belorusskoje } \\
\text { Malinovoje' }\end{array}$} & Control & $3.57 b$ & $2.23 a$ \\
\hline & $0.8 \mathrm{ppm}$ & $4.92 a$ & $2.04 a$ \\
\hline & 3.0 ppm & $0.00 c$ & $1.51 \mathrm{a}$ \\
\hline \multirow[t]{3}{*}{ 'Gita' } & Control & $26.67 b$ & $0.00 \mathrm{~b}$ \\
\hline & $0.8 \mathrm{ppm}$ & $30.61 a$ & $1.97 a$ \\
\hline & $3.0 \mathrm{ppm}$ & $27.08 b$ & $2.52 a$ \\
\hline
\end{tabular}

Note: Values for the same cultivar followed by different small letters are significantly different by the LSD at 0.05 level (differences between storage conditions).

Apple flesh firmness is dependent on the degree of ripeness, place of growing, weather conditions and cultivar. Flesh firmness decreases during fruit ripening; therefore, for all cultivars, the highest firmness has been observed before storage, and storage technology significantly affects the firmness of the apples (Juhņeviča-Radenkova and Radenkovs, 2016).

Data depicted in Table 3 indicate that at the beginning of long-term storage, flesh firmness fluctuated in a range from $34.58 \mathrm{~N}$ to $63.46 \mathrm{~N}$.

During long-term storage, considerably lower loss of firmness was noted in the case of cold storage without ozone treatment, as well as when ozone-treated at a concentration of $0.8 \mathrm{ppm}$ was applied. Significantly higher flesh firmness was noted in 'Iedzenu' apples $(43.23 \mathrm{~N}$ and $42.60 \mathrm{~N})$ subjected to $\mathrm{O}_{3}$ exposure at concentrations of $0.8 \mathrm{ppm}$ and $3.0 \mathrm{ppm}$, respectively. With regard to other cultivars, no significant differences were found between treated and untreated fruit. Taking into account the results obtained after shelf life, it is evident that significantly better preservation of flesh firmness was achieved when 'Iedzenu' $(38.54 \mathrm{~N}$ and $40.61 \mathrm{~N})$ apples were treated with ozone at the concentrations of 0.8 and $3.0 \mathrm{ppm}$, respectively. Due to a lack of scientific research concerning $\mathrm{O}_{3}$ influence on apple quality, it is not possible to compare the results obtained within this research. In some papers, $\mathrm{O}_{3}$ has made a significant (Liu et al., 2016) and little (Miller et al., 2013) impact on maintaining the firmness of fresh-cut apples.
Table 2. Fresh weight loss of apples stored under different conditions, \%.

\begin{tabular}{|c|c|c|c|}
\hline \multirow[b]{2}{*}{ Cultivar } & \multirow[b]{2}{*}{$\begin{array}{l}\text { Ozone } \\
\text { concentration }\end{array}$} & \multicolumn{2}{|c|}{ Storage time } \\
\hline & & $\begin{array}{l}\text { After six } \\
\text { months of } \\
\text { storage }\end{array}$ & $\begin{array}{l}\text { After shelf } \\
\text { life of } \\
\text { five days }\end{array}$ \\
\hline \multirow[t]{3}{*}{ ‘ledzenu’ } & Control & $10.00 a$ & $0.06 b$ \\
\hline & 0.8 ppm & $10.25 a$ & $0.08 b$ \\
\hline & 3.0 ppm & $6.50 \mathrm{~b}$ & $0.24 a$ \\
\hline \multirow[t]{3}{*}{ 'Auksis' } & Control & $1.67 c$ & $0.10 a$ \\
\hline & 0.8 ppm & $15.19 a$ & $0.06 \mathrm{~b}$ \\
\hline & 3.0 ppm & $6.73 b$ & $0.18 a$ \\
\hline \multirow{3}{*}{$\begin{array}{l}\text { 'Belorusskoje } \\
\text { Malinovoje' }\end{array}$} & Control & $4.90 a$ & $0.12 a$ \\
\hline & 0.8 ppm & $5.00 \mathrm{a}$ & $0.12 a$ \\
\hline & 3.0 ppm & $4.51 b$ & $0.10 \mathrm{a}$ \\
\hline \multirow[t]{3}{*}{ ‘Gita’ } & Control & $6.12 \mathrm{c}$ & $0.00 \mathrm{~b}$ \\
\hline & $0.8 \mathrm{ppm}$ & $7.45 b$ & $0.08 a$ \\
\hline & 3.0 ppm & $29.41 a$ & $0.10 a$ \\
\hline
\end{tabular}

Note: Values for the same cultivar followed by different small letters are significantly different by the LSD at 0.05 level (differences between storage conditions).

The main acids in apples are malic acid, citric acid and tartaric acid, and their levels depend on the cultivar and the degree of ripeness. During ripening, as well as storage, the level of acids in apples decreases due to the activity of endogenous enzymes. Data depicted in Table 4 indicate that at the beginning of storage, a higher titratable acidity was observed, corresponding to values from $0.41 \%$ to $0.73 \%$, while after long-term storage, it considerably declined. The analysis of variance showed no significant difference $(p>0.05)$ for titratable acidity from the interaction of treatment or no treatment with $\mathrm{O}_{3}$, except the cultivar 'Gita' apples (concentration of $0.8 \mathrm{ppm}$ ).

After shelf life, a significantly higher $(p<0.05)$ titratable acidity was found in untreated apples, which were kept under normal conditions, while no impact was observed on a cultivar of 'Gita' apples. Our findings coincide with the results of Alencar et al. (2014), who pointed out that there was no statistically significant effect of $(p<0.05)$ of $\mathrm{O}_{3}$ at a concentration of

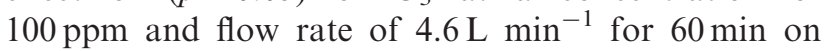
titratable acidity in pears (Pyrus communis cv. 'Williams'). Contrarily, a positive impact (Heleno et al., 2015) on table grape (Vitis vinifera L.) fruits subjected to treatment with $2 \mathrm{mg} \mathrm{L}^{-1}$ of gaseous $\mathrm{O}_{3}$ within seven weeks of storage has been achieved.

The analysis of variance showed a significant difference $(p<0.05)$ after long-term apple storage for total soluble solids (TSS) from the interaction of treatment 
Table 3. Flesh firmness of apples stored under different conditions, $n$.

\begin{tabular}{|c|c|c|c|c|}
\hline \multirow[b]{2}{*}{ Cultivar } & \multirow[b]{2}{*}{$\begin{array}{l}\text { Ozone } \\
\text { concentration }\end{array}$} & \multicolumn{3}{|l|}{ Storage time } \\
\hline & & Before storage & $\begin{array}{l}\text { After six months } \\
\text { of storage }\end{array}$ & $\begin{array}{l}\text { After shelf life } \\
\text { of five days }\end{array}$ \\
\hline \multirow[t]{3}{*}{ ‘ledzenu’ } & Control & $63.46 \pm 5.54$ & $39.60 b \pm 5.73$ & $28.91 b \pm 6.38$ \\
\hline & $0.8 \mathrm{ppm}$ & & $43.23 a \pm 9.51$ & $38.54 a \pm 5.45$ \\
\hline & $3.0 \mathrm{ppm}$ & & $42.60 a \pm 6.87$ & $40.61 \mathrm{a} \pm 7.83$ \\
\hline \multirow[t]{3}{*}{ 'Auksis' } & Control & $38.64 \pm 4.19$ & $38.14 a \pm 7.68$ & $28.65 a \pm 3.47$ \\
\hline & $0.8 \mathrm{ppm}$ & & $31.92 b \pm 7.98$ & $29.95 a \pm 6.31$ \\
\hline & $3.0 \mathrm{ppm}$ & & $36.51 a \pm 5.52$ & $31.02 \mathrm{a} \pm 6.05$ \\
\hline \multirow[t]{3}{*}{ ‘Belorusskoje Malinovoje’ } & Control & $49.55 \pm 3.57$ & $32.64 a \pm 2.93$ & $31.51 \mathrm{a} \pm 3.21$ \\
\hline & 0.8 ppm & & $31.36 a \pm 2.25$ & $31.30 a \pm 3.40$ \\
\hline & $3.0 \mathrm{ppm}$ & & $32.10 a \pm 3.29$ & $26.25 b \pm 6.33$ \\
\hline \multirow[t]{3}{*}{ 'Gita' } & Control & $34.58 \pm 4.19$ & $32.02 \mathrm{a} \pm 4.47$ & $22.72 \mathrm{a} \pm 4.13$ \\
\hline & $0.8 \mathrm{ppm}$ & & $29.79 a \pm 4.70$ & $26.46 a \pm 3.34$ \\
\hline & $3.0 \mathrm{ppm}$ & & $33.13 a \pm 5.20$ & $23.16 a \pm 6.27$ \\
\hline
\end{tabular}

Note: Values for the same cultivar followed by different small letters are significantly different by the LSD at 0.05 level (differences between storage conditions).

Table 4. Titratable acidity of apples stored under different conditions, \%.

\begin{tabular}{|c|c|c|c|c|}
\hline \multirow[b]{2}{*}{ Cultivar } & \multirow[b]{2}{*}{$\begin{array}{l}\text { Ozone } \\
\text { concentration }\end{array}$} & \multicolumn{3}{|l|}{ Storage time } \\
\hline & & Before storage & $\begin{array}{l}\text { After six months } \\
\text { of storage }\end{array}$ & $\begin{array}{l}\text { After shelf life } \\
\text { of five days }\end{array}$ \\
\hline \multirow[t]{3}{*}{ 'ledzenu’ } & Control & 0.41 & $0.38 a$ & $0.51 \mathrm{a}$ \\
\hline & $0.8 \mathrm{ppm}$ & & $0.38 a$ & $0.38 b$ \\
\hline & $3.0 \mathrm{ppm}$ & & $0.38 a$ & $0.38 b$ \\
\hline \multirow[t]{3}{*}{ 'Auksis' } & Control & 0.45 & $0.38 a$ & $0.38 a$ \\
\hline & $0.8 \mathrm{ppm}$ & & $0.38 a$ & $0.38 a$ \\
\hline & $3.0 \mathrm{ppm}$ & & $0.38 a$ & $0.38 a$ \\
\hline \multirow[t]{3}{*}{ 'Belorusskoje Malinovoje' } & Control & 0.73 & $0.57 a$ & $0.64 a$ \\
\hline & $0.8 \mathrm{ppm}$ & & $0.51 a$ & $0.51 b$ \\
\hline & $3.0 \mathrm{ppm}$ & & $0.51 a$ & $0.51 b$ \\
\hline \multirow[t]{3}{*}{ 'Gita' } & Control & 0.67 & $0.51 a$ & $0.45 a$ \\
\hline & $0.8 \mathrm{ppm}$ & & $0.45 b$ & $0.38 \mathrm{a}$ \\
\hline & $3.0 \mathrm{ppm}$ & & $0.57 a$ & $0.45 a$ \\
\hline
\end{tabular}

Note: Values for the same cultivar followed by different small letters are significantly different by the LSD at 0.05 level (differences between storage conditions).

or no treatment with ozone. Mean values with standard deviation are shown in Table 5. Ozone-treated (concentration of $3.0 \mathrm{ppm}$ ) apples as well as untreated apples reached the highest TSS concentration after long-term storage. As can be seen, the higher TSS value is observed in the cultivar 'Iedzenu' samples that were ozone treated with a concentration of $3.0 \mathrm{ppm}$, cultivar 'Auksis' samples treated with a concentration of $0.8 \mathrm{ppm}$ and cultivar 'Gita' samples: both treated (concentration of $3.0 \mathrm{ppm}$ ) and untreated apples. Taking into consideration the results presented in literature, it becomes apparent that in the majority of published papers, there is no evidence regarding significant influence of ozonation on TSS content (Miller et al., 2013).

However, Alegria et al. (2009) noted a significant decrease of TSS content in ozonated carrots. The authors came to the conclusion that the decrease of 
Table 5. Total soluble solids content of apples stored under different conditions, ${ }^{\circ}$ Brix.

\begin{tabular}{|c|c|c|c|c|}
\hline \multirow[b]{2}{*}{ Cultivar } & \multirow[b]{2}{*}{$\begin{array}{l}\text { Ozone } \\
\text { concentration }\end{array}$} & \multicolumn{3}{|l|}{ Storage time } \\
\hline & & Before storage & $\begin{array}{l}\text { After six months } \\
\text { of storage }\end{array}$ & $\begin{array}{l}\text { After shelf life } \\
\text { of five days }\end{array}$ \\
\hline \multirow[t]{3}{*}{ ‘ledzenu’ } & Control & $11.75 \pm 0.15$ & $12.41 b \pm 0.25$ & $11.43 a \pm 0.05$ \\
\hline & $0.8 \mathrm{ppm}$ & & $11.65 c \pm 0.20$ & $11.04 a \pm 0.11$ \\
\hline & $3.0 \mathrm{ppm}$ & & $13.42 \mathrm{a} \pm 0.13$ & $11.09 a \pm 0.13$ \\
\hline \multirow[t]{3}{*}{ 'Auksis' } & Control & $12.33 \pm 0.19$ & $11.16 b \pm 0.39$ & $11.63 a \pm 0.15$ \\
\hline & $0.8 \mathrm{ppm}$ & & $12.16 \mathrm{a} \pm 0.57$ & $11.63 a \pm 0.07$ \\
\hline & $3.0 \mathrm{ppm}$ & & $11.61 a b \pm 0.05$ & $11.78 a \pm 0.10$ \\
\hline \multirow[t]{3}{*}{ 'Belorusskoje Malinovoje' } & Control & $11.03 \pm 0.20$ & $10.51 a \pm 0.27$ & $9.72 b \pm 0.38$ \\
\hline & $0.8 \mathrm{ppm}$ & & $9.95 b \pm 0.18$ & $11.06 a \pm 0.09$ \\
\hline & $3.0 \mathrm{ppm}$ & & $10.54 a \pm 0.50$ & $9.19 b \pm 0.03$ \\
\hline \multirow[t]{3}{*}{ ‘Gita’ } & Control & $12.16 \pm 0.25$ & $11.66 a \pm 0.29$ & $10.97 a \pm 0.05$ \\
\hline & $0.8 \mathrm{ppm}$ & & $10.64 b \pm 0.41$ & $10.07 a \pm 0.17$ \\
\hline & $3.0 \mathrm{ppm}$ & & $11.24 a \pm 0.14$ & $10.91 a \pm 0.14$ \\
\hline
\end{tabular}

Note: Values for the same cultivar followed by different small letters are significantly different by the LSD at 0.05 level (differences between storage conditions).

TSS was caused by the leaching process. The analysis of variance showed that after apple shelf life, only in one case a significant difference $(p<0.05)$ was observed for 'Belorusskoje Malinovoje', where higher TSS recorded in treated with $0.8 \mathrm{ppm}$ fruits. Our results indicate that there were no significant differences for TSS between treated and untreated apple fruits. Similar observations have been introduced by various researchers, who pointed out that $\mathrm{O}_{3}$ treatment has no effect on preservation of TSS in table grape (Tzortzakis et al., 2007), melon (Selma et al., 2007) and tomatoes (Venta et al., 2010). The content of TSS decreased overall for all samples after five days of shelf life, indicating a continuation of the ripening process.

Different chemical compounds are liable for the colour changes, depending on the type of fruits. For instance, different phenolics, such as flavonols, phloridzin and hydroxycinnamic acids, can contribute to colour characteristics in apple (Sanoner et al., 1999). The Hunter colour values of apples after longterm storage under normal atmosphere conditions only or in combination with treatment of ozone are shown in Table 6. $L^{*}, a^{*}$ and $b^{*}$ values of treated samples were significantly different $(p>0.05)$ from those of the control samples. After ozonation, the apple samples became lighter ('Gita' $-0.8 \mathrm{ppm}$ ), redder ('Auksis' - 3.0 ppm) and yellower ('Gita' $0.8 \mathrm{ppm}$ and 'Iedzenu' $-3.0 \mathrm{ppm})$ in colour, i.e. increased $L^{*}, a^{*}$ and $b^{*}$ with values. However, the change in colour depended on the cultivar of apples. Within the literature, contradictory observations were found, which stated that the colour of apple juice (Patil et al., 2010; Torres et al., 2011)
Table 6. Colour of apples stored under different conditions, $L^{*}, a^{*}$ and $b^{*}$.

\begin{tabular}{lcccc}
\hline & \multirow{4}{c}{ Ozone } & \multicolumn{3}{c}{ After six months of storage } \\
\cline { 3 - 5 } Cultivar & concentration & $L^{*}$ & $a^{*}$ & $b^{*}$ \\
\hline Control & $50.45 \mathrm{a}$ & $7.23 \mathrm{~b}$ & $29.68 \mathrm{c}$ & \\
'ledzenu' & $0.8 \mathrm{ppm}$ & $52.65 \mathrm{a}$ & $4.47 \mathrm{c}$ & $35.67 \mathrm{~b}$ \\
& $3.0 \mathrm{ppm}$ & $52.3 \mathrm{a}$ & $12.4 \mathrm{a}$ & $44.27 \mathrm{a}$ \\
'Auksis' & Control & $62.12 \mathrm{a}$ & $-1.77 \mathrm{~b}$ & $39.29 \mathrm{a}$ \\
& $0.8 \mathrm{ppm}$ & $61.9 \mathrm{a}$ & $-1.12 \mathrm{~b}$ & $40.09 \mathrm{a}$ \\
& $3.0 \mathrm{ppm}$ & $40.47 \mathrm{~b}$ & $20.71 \mathrm{a}$ & $26.6 \mathrm{~b}$ \\
'Belorusskoje & Control & $49.85 \mathrm{a}$ & $2.63 \mathrm{~b}$ & $25.79 \mathrm{c}$ \\
Malinovoje' & $0.8 \mathrm{ppm}$ & $49.96 \mathrm{a}$ & $4.93 \mathrm{a}$ & $31.4 \mathrm{~b}$ \\
& $3.0 \mathrm{ppm}$ & $47.66 \mathrm{a}$ & $4.11 \mathrm{a}$ & $34.36 \mathrm{a}$ \\
'Gita' & Control & $60.95 \mathrm{~b}$ & $-2.67 \mathrm{ab}$ & $37.41 \mathrm{~b}$ \\
& $0.8 \mathrm{ppm}$ & $67.51 \mathrm{a}$ & $-3.84 \mathrm{a}$ & $45.96 \mathrm{a}$ \\
& $3.0 \mathrm{ppm}$ & $62.74 \mathrm{~b}$ & $-1.09 \mathrm{~b}$ & $33.25 \mathrm{c}$ \\
\hline
\end{tabular}

Note: Values for the same cultivar followed by different small letters are significantly different by the LSD at 0.05 level (differences between storage conditions).

and grape (Tiwari et al., 2009) could be deteriorated due to ozone processing.

In contrast, Sung et al. (2014) noted that ozone treatment had no effect on the colour value of apple juice. To the best of our knowledge, this is the first report that examines the effect of ozone treatment of apple quality.

PCA was performed on the sensory data (Tables 7 and 8) of the four analysed apple cultivars that were 
Table 7. Sensory evaluation results of samples after six months of storage.

\begin{tabular}{|c|c|c|c|c|c|c|c|c|}
\hline \multirow[b]{2}{*}{ Cultivar } & \multirow{2}{*}{$\begin{array}{l}\text { Ozone } \\
\text { concentration }\end{array}$} & \multicolumn{7}{|c|}{ After six months of storage } \\
\hline & & App & Aro & Tas & Pre & Aci & Swe & Jui \\
\hline & Control & $3.5 b c \pm 0.4$ & $2.7 a b \pm 1.2$ & $3.7 a \pm 0.4$ & $4.8 a \pm 0.4$ & $2.9 a b c \pm 0.9$ & $3.6 a b \pm 0.5$ & $3.0 a b \pm 0.6$ \\
\hline \multirow[t]{2}{*}{ ‘ledzenu’ } & $0.8 \mathrm{ppm}$ & $3.0 \mathrm{~d} \pm 0.7$ & $2.5 \pm b c \pm 1.0$ & $3.5 a b \pm 0.4$ & $4.6 a b \pm 0.9$ & $3.1 a b \pm 0.7$ & $3.7 a b \pm 0.4$ & $2.5 b \pm 0.5$ \\
\hline & $3.0 \mathrm{ppm}$ & $2.7 e \pm 0.8$ & $2.0 \pm d \pm 0.7$ & $3.4 a b \pm c 0.7$ & $4.5 \mathrm{ab} \pm 0.9$ & $2.7 \mathrm{bcd} \pm 1.0$ & $3.6 a b \pm 0.7$ & $2.9 b \pm 0.3$ \\
\hline \multirow[t]{3}{*}{ 'Auksis' } & Control & $4.1 a \pm 0.2$ & $2.6 a b \pm 1.1$ & $3.3 a b c \pm 0.8$ & $4.4 a b \pm 1.3$ & $2.3 d \pm 1.0$ & $3.1 \mathrm{~cd} \pm 0.8$ & $2.6 b \pm 0.7$ \\
\hline & $0.8 \mathrm{ppm}$ & $3.7 a b \pm 0.5$ & $2.3 c \pm 1.0$ & $2.9 \mathrm{~cd} \pm 1.0$ & $4.4 a b \pm 1.3$ & $2.5 \mathrm{~cd} \pm 0.9$ & $3.1 \mathrm{~cd} \pm 1.0$ & $2.9 b \pm 0.2$ \\
\hline & $3.0 \mathrm{ppm}$ & $3.5 b c \pm 0.4$ & $2.3 c \pm 0.4$ & $2.7 d \pm 0.5$ & $4.4 a b \pm 1.3$ & $2.6 \mathrm{bcd} \pm 0.4$ & $3.4 b c \pm 0.8$ & $2.9 b \pm 0.2$ \\
\hline \multirow{3}{*}{$\begin{array}{r}\text { 'Belorusskoje } \\
\text { Malinovoje' }\end{array}$} & Control & $3.1 d \pm 0.4$ & $2.5 b c \pm 0.1$ & $3.2 b c \pm 0.9$ & $4.4 a b \pm 1.3$ & $2.9 a b c \pm 1.0$ & $2.6 e \pm 1.0$ & $3.4 a b \pm 0.5$ \\
\hline & $0.8 \mathrm{ppm}$ & $2.5 \mathrm{ef} \pm 0.8$ & $2.4 c \pm 1.0$ & $2.1 \mathrm{e} \pm 0.6$ & $4.2 b \pm 0.9$ & $2.3 d \pm 0.7$ & $2.4 \mathrm{e} \pm 0.7$ & $1.7 c \pm 0.8$ \\
\hline & $3.0 \mathrm{ppm}$ & $2.3 f \pm 0.5$ & $2.3 c \pm 0.4$ & $2.6 d \pm 1.0$ & $4.4 a b \pm 1.3$ & $3.0 a b c \pm 0.8$ & $2.8 \mathrm{de} \pm 0.5$ & $2.5 b \pm 0.7$ \\
\hline \multirow[t]{3}{*}{ ‘Gita’ } & Control & $3.2 \mathrm{~cd} \pm 1.2$ & $3.0 \mathrm{a} \pm 1.2$ & $3.5 a b \pm 0.8$ & $4.4 a b \pm 1.3$ & $3.3 a \pm 0.9$ & $2.9 \mathrm{cde} \pm 0.8$ & $3.0 a b \pm 1.4$ \\
\hline & $0.8 \mathrm{ppm}$ & $3.1 \mathrm{~d} \pm 0.5$ & $2.5 b c \pm 1.1$ & $3.0 \mathrm{bcd} \pm 1.1$ & $4.5 a b \pm 1.8$ & $3.1 a b \pm 1.3$ & $2.5 e \pm 1.0$ & $3.0 a b \pm 0.7$ \\
\hline & $3.0 \mathrm{ppm}$ & $3.0 \mathrm{~d} \pm 0.4$ & $2.3 c \pm 1.0$ & $2.9 c d \pm 0.5$ & $4.4 a b \pm 1.3$ & $2.8 a b c \pm 1.0$ & $2.6 e \pm 0.8$ & $2.9 b \pm 0.9$ \\
\hline
\end{tabular}

Note: Sensory attributes: App: appearance, Aro: aroma, Tas: taste, Pre: maturity stage, Aci: acidity, Swe: sweetness, Jui: juiciness. Values for the same cultivar followed by different small letters are significantly different by the LSD at 0.05 level (differences between storage conditions).

Table 8. Sensory evaluation results of samples after shelf-life storage.

\begin{tabular}{|c|c|c|c|c|c|c|c|c|}
\hline \multirow[b]{2}{*}{ Cultivar } & \multirow{2}{*}{$\begin{array}{l}\text { Ozone } \\
\text { concentration }\end{array}$} & \multicolumn{7}{|c|}{ After additional five days of shelf-life } \\
\hline & & App & Aro & Tas & Pre & Aci & Swe & Jui \\
\hline & Control & $3.4 a b \pm 0.5$ & $2.7 a b \pm 0.6$ & $3.4 a \pm 0.5$ & $3.7 a b \pm 1.2$ & $2.6 \mathrm{~cd} \pm 1.1$ & $3.2 \mathrm{ab} \pm 0.5$ & $3.0 b c \pm 0.3$ \\
\hline \multirow[t]{2}{*}{ 'ledzenu’ } & $0.8 \mathrm{ppm}$ & $2.1 \mathrm{ef} \pm 0.7$ & $2.6 \mathrm{adc} \pm 0.5$ & $3.2 \mathrm{a} \pm 0.5$ & $3.6 a b \pm 1.2$ & $2.8 b c \pm 1.1$ & $3.4 a \pm 0.5$ & $3.8 a \pm 0.4$ \\
\hline & $3.0 \mathrm{ppm}$ & 1.9 ef \pm 0.5 & $2.5 a b c d \pm 0.5$ & $3.3 a \pm 0.8$ & $3.8 \mathrm{a} \pm 1.2$ & $2.6 \mathrm{~cd} \pm 1.0$ & $3.4 a \pm 0.9$ & $3.7 a \pm 0.5$ \\
\hline \multirow[t]{3}{*}{ 'Auksis' } & Control & $3.0 b \pm 0.3$ & $2.6 a b c \pm 1.0$ & $3.1 \mathrm{a} \pm 0.8$ & $3.2 \mathrm{~cd} \pm 1.6$ & $2.6 \mathrm{~cd} \pm 1.3$ & $3.2 \mathrm{a} \pm 0.8$ & $2.6 c \pm 0.8$ \\
\hline & $0.8 \mathrm{ppm}$ & $2.8 \mathrm{~cd} \pm 1.0$ & $2.3 \mathrm{~cd} \pm 0.4$ & $3.0 \mathrm{a} \pm 0.8$ & $3.3 b \pm 1.4$ & $2.6 \mathrm{~cd} \pm 0.8$ & $2.8 \mathrm{bc} \pm 0.5$ & $3.0 b \pm 0.3$ \\
\hline & $3.0 \mathrm{ppm}$ & $3.7 \mathrm{a} \pm 0.4$ & $2.7 a b \pm 0.8$ & $3.1 \mathrm{a} \pm 0.5$ & $3.7 a b \pm 1.2$ & $3.2 a b \pm 0.8$ & $3.1 \mathrm{a} \pm 0.5$ & $3.4 b \pm 0.5$ \\
\hline \multirow{3}{*}{$\begin{array}{l}\text { ‘Belorusskoje } \\
\text { Malinovoje' }\end{array}$} & Control & $3.1 b c \pm 0.4$ & $2.8 a b \pm 0.8$ & $3.0 \mathrm{a} \pm 0.5$ & $3.3 b \pm 1.4$ & $3.1 \mathrm{a} \pm 0.5$ & $2.4 c d \pm 0.9$ & $2.8 c \pm 1.1$ \\
\hline & $0.8 \mathrm{ppm}$ & $2.8 \mathrm{~cd} \pm 1.2$ & $2.7 a b \pm 0.5$ & $3.0 \mathrm{a} \pm 0.6$ & $3.5 a \pm 1.2$ & $3.1 \mathrm{a} \pm 0.6$ & $3.0 a \pm 0.6$ & $3.4 a \pm 0.5$ \\
\hline & $3.0 \mathrm{ppm}$ & $3.3 a \pm 0.8$ & $3.0 a \pm 0.7$ & $3.1 \mathrm{a} \pm 0.5$ & $3.7 a b \pm 1.2$ & $3.6 \mathrm{a} \pm 0.7$ & $3.1 \mathrm{a} \pm 0.9$ & $3.5 a \pm 0.5$ \\
\hline \multirow[t]{3}{*}{ 'Gita’ } & Control & $2.4 \mathrm{de} \pm 0.9$ & $2.4 b \pm 1.1$ & $2.2 b \pm 0.8$ & $2.3 e \pm 1.5$ & $2.3 d \pm 1.3$ & $1.7 e \pm 0.5$ & $1.8 \mathrm{~d} \pm 0.9$ \\
\hline & $0.8 \mathrm{ppm}$ & $1.6 f \pm 0.7$ & $2.0 \mathrm{~d} \pm 1.3$ & $2.0 b \pm 1.1$ & $2.8 \mathrm{~d} \pm 1.8$ & $2.2 \mathrm{de} \pm 1.3$ & $2.0 \mathrm{de} \pm 1.3$ & $2.0 \mathrm{~d} \pm 1.3$ \\
\hline & $3.0 \mathrm{ppm}$ & $2.1 \mathrm{ef} \pm 0.7$ & $2.2 \mathrm{~d} \pm 1.2$ & $1.8 b \pm 0.8$ & $2.3 e \pm 1.5$ & $1.8 \mathrm{e} \pm 1.0$ & $2.2 \mathrm{~d} \pm 1.0$ & $1.8 \mathrm{~d} \pm 1.0$ \\
\hline
\end{tabular}

Note: Sensory attributes: App: appearance, Aro: aroma, Tas: taste, Pre: maturity stage, Aci: acidity, Swe: sweetness, Jui: juiciness. Values for the same cultivar followed by different small letters are significantly different by the LSD at 0.05 level (differences between storage conditions).

kept under different long-term conditions (Figure 9(a)after six months cold storage; (b) - after six months cold storage + additionally 5 days of shelf life). PC1 and PC2 together explain 78.9 and $91.3 \%$ of the samples' variance, respectively. As can be seen in Figure 9(a), clear separation (the upper and the lower left side of cultivar 'Iedzenu' apples (IE_C and IE_0.8 ppm) is observed, and those samples were kept separate of other apple samples. These apple samples were characterized as fruits with the most pronounced aroma, acidity, sweetness, taste and better maturity stage. Furthermore, apple samples: BM_C;
BM_0.8 ppm; BM_3.0 ppm; AU_C; AU_0.8 ppm have been highlighted as samples with pronounced juiciness and appearance. Taking into account the results after long-term apple storage + five additional days of shelf life, one can conclude that apples that were ozone treated (with concentrations 0.8 and $3.0 \mathrm{ppm}$ ), particularly cultivars 'Belorusskoje Malinovoje' and 'Auksis' (BM_3.0 ppm; AU_3.0 ppm), were characterised as the most acidic, fragrant and having the best appearance, whereas cultivar of 'Iedzenu' apples treated with ozone at both concentrations of 0.8 and $3.0 \mathrm{ppm}$ had the most pronounced sweetness, taste, juiciness 


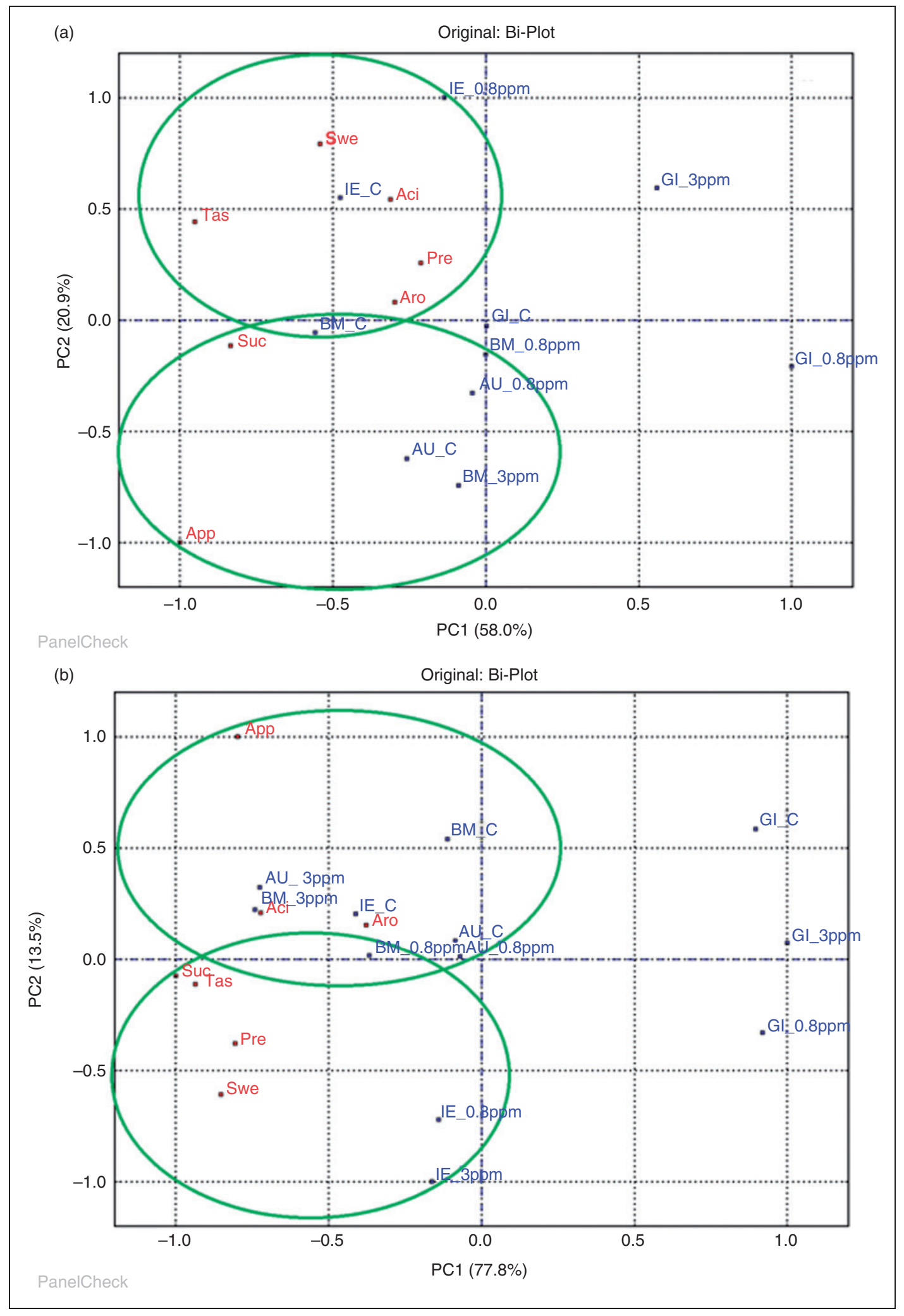

Figure 9. Biplot presenting the scores and loadings of the first two principal components of apple sensory data (a - after six months' storage, $b$ - after five days of shelf life).

Note: Letters represented in the figures indicate the types of storage: C: cold storage; $0.8 \mathrm{ppm}$ : ozone concentration $0.8 \mathrm{ppm}$; 3 ppm: ozone concentration 3 ppm. Cultivars: Au: 'Auksis'; Gl: 'Gita'; IE: 'ledzenu'; BM: 'Belorusskoje Malinovoje'. Attributes: App: appearance; Aro: aroma; Tas: taste; Pre: maturity stage; Aci: acidity; Swe: sweetness; Suc: juiciness. 


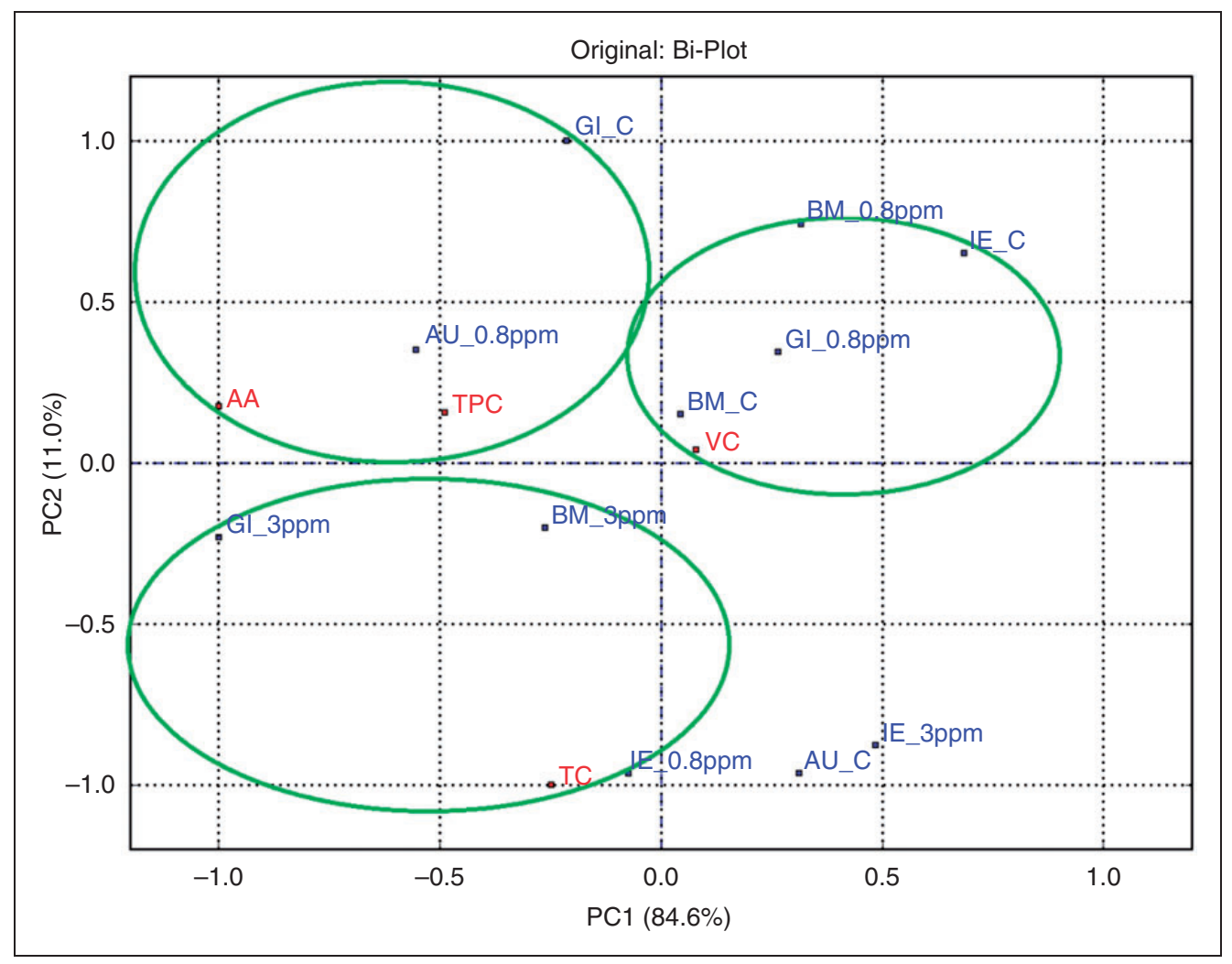

Figure 10. Biplot presenting scores and loadings of the first two principal components of apple chemical composition. Notes: Letters represented in the figures indicate the types of storage: $\mathrm{C}$ : cold storage; $0.8 \mathrm{ppm}$ : ozone concentration $0.8 \mathrm{ppm}$; $3 \mathrm{ppm}$ : ozone concentration $3 \mathrm{ppm}$. Cultivars: Au -'Auksis'; Gl: 'Gita'; IE -'ledzenu'; BM -'Belorusskoje Malinovoje'. Attributes: VC: Vitamin C; TPC: total phenolic content; TC: tannin content; AA: antioxidant activity.

and better maturity stage. In conclusion, it should be mentioned that apple cold storage with a combination of ozone treatments can be used as a novel technology that is capable of preserving sensory quality of apples during long-term storage and during shelf life as well.

Antioxidants comprise a wide range of constituents that have the ability to scavenge free radicals, preventing oxidative food damage. These substances act as antimicrobial and anticarcinogenic agents, and they possess health-protective functions. The antioxidants capacity in fruits mainly depends on the presence of polyphenols, vitamin $\mathrm{C}$, anthocyanins and carotenoids (Miller et al., 2013). Therefore, it is desirable to determine the content of antioxidants in apples and their activity against free radicals and to quantitatively define the effect of ozone on the biochemical profile of apples.

PCA was performed on the data of the four analysed apple cultivars that were kept for under different longterm conditions (Figure 10 and Table 9). PC1 and PC2 together explain $95.6 \%$ of the samples' variance. In Figure 10, clear separation of three groups is evident (the upper and the lower left side and the upper right side). It was observed that for the 'Gita' (GI_C) and 'Auksis' (AU_0.8 ppm) samples, the antioxidant capacity (determined by using DPPH method) had a strong positive correlation with total phenolics. Cultivar 'Auksis' (AU_0.8 ppm) apples among other samples contained the highest amount of phenolics. In turn, total tannins were found to be dominant in the apple cultivars 'Gita' (GI_3 ppm), 'Iedzenu' (IE_0.8 ppm) and 'Belorusskoje Malinovoje' (BM_3.0 ppm), while vitamin $\mathrm{C}$ was dominant in the 'Belorusskoje Malinovoje' (BM_C), 'Gita' (GI_0.8 ppm), and 'Iedzenu' (IE_C) samples. This phenomenon could be explained by the ability of ozone induce or even enhance the production of the phenolics in plants (Forney, 2003). It is also explainable by the plant's natural tolerance to environmental abiotic stress conditions caused by many factors (heat, frost, cold, ozone, salinity, etc.). Torres et al. (2011) found that ozonation as a preservation technique for processing of apple juice is very useful; nutritional value of the produce can be altered, with the key factor being exposure time. 
Table 9. Total vitamin C, phenolic, tannin content and antioxidant activity of four apple cultivars stored under different conditions.

\begin{tabular}{llrrll}
\hline \multirow{2}{*}{ Cultivar } & $\begin{array}{l}\text { Ozone } \\
\text { concentration }\end{array}$ & \multicolumn{2}{l}{ After six months of storage } \\
\cline { 2 - 5 } 'ledzenu' & Control & $16.86 \mathrm{mg} \pm 0.17$ & $66.33 \mathrm{~b} \pm 5.56$ & $25.16 \mathrm{c} \pm 5.19$ & $109.40 \mathrm{c} \pm 4.69$ \\
& $0.8 \mathrm{ppm}$ & $12.94 \mathrm{c} \pm 0.42$ & $91.97 \mathrm{a} \pm 5.58$ & $58.15 \mathrm{a} \pm 3.65$ & $138.43 \mathrm{a} \pm 5.02$ \\
& $3.0 \mathrm{ppm}$ & $14.60 \mathrm{~b} \pm 0.42$ & $64.98 \mathrm{c} \pm 1.81$ & $48.96 \mathrm{~b} \pm 3.32$ & $117.18 \mathrm{~b} \pm 3.26$ \\
'Auksis' & Control & $7.43 \mathrm{~b} \pm 0.42$ & $72.14 \mathrm{c} \pm 4.69$ & $52.23 \mathrm{a} \pm 3.34$ & $123.71 \mathrm{c} \pm 3.15$ \\
& $0.8 \mathrm{ppm}$ & $8.01 \mathrm{a} \pm 0.33$ & $107.80 \mathrm{a} \pm 0.95$ & $44.63 \mathrm{~b} \pm 4.07$ & $171.93 \mathrm{~b} \pm 4.91$ \\
& $3.0 \mathrm{ppm}$ & $8.10 \mathrm{a} \pm 0.58$ & $100.57 \mathrm{a} \pm 1.94$ & $49.04 \mathrm{a} \pm 3.54$ & $198.25 \mathrm{a} \pm 5.30$ \\
'Belorusskoje & Control & $16.36 \mathrm{a} \pm 0.33$ & $90.01 \mathrm{a} \pm 6.14$ & $40.98 \mathrm{~b} \pm 4.57$ & $136.15 \mathrm{~b} \pm 5.89$ \\
Malinovoje' & $0.8 \mathrm{ppm}$ & $13.10 \mathrm{~b} \pm 0.58$ & $85.88 \mathrm{c} \pm 0.97$ & $29.09 \mathrm{c} \pm 4.81$ & $122.90 \mathrm{c} \pm 6.36$ \\
& $3.0 \mathrm{ppm}$ & $13.09 \mathrm{~b} \pm 0.17$ & $87.06 \mathrm{~b} \pm 0.84$ & $53.64 \mathrm{a} \pm 4.23$ & $155.56 \mathrm{a} \pm 4.58$ \\
'Gita' & Control & $9.01 \mathrm{~b} \pm 0.19$ & $89.97 \mathrm{~b} \pm 6.22$ & $31.43 \mathrm{c} \pm 2.88$ & $155.10 \mathrm{~b} \pm 3.49$ \\
& $0.8 \mathrm{ppm}$ & $10.60 \mathrm{a} \pm 0.42$ & $72.97 \mathrm{c} \pm 4.50$ & $34.24 \mathrm{~b} \pm 3.08$ & $131.04 \mathrm{c} \pm 5.82$ \\
& $3.0 \mathrm{ppm}$ & $7.51 \mathrm{c} \pm 0.50$ & $94.37 \mathrm{~b} \pm 2.17$ & $58.75 \mathrm{a} \pm 1.75$ & $191.23 \mathrm{a} \pm 1.45$ \\
\hline
\end{tabular}

Note: Values for the same cultivar followed by different small letters are significantly different by the LSD at 0.05 level (differences between storage conditions).

Attributes: VC: vitamin C; TPC: total phenolic content; TC: tannin content; AA: antioxidant activity.

\section{CONCLUSIONS}

The present work investigated the effect of ozone treatment on the postharvest quality of four cultivars of apples. The results have shown that the ozone treatment of fruits during long-term storage has a minor effect on cellular membranes, cell integrity and changes in epicuticular waxes structure. Ozone application could accelerate the natural ageing of the waxes found on the surface of apples, thereby reducing the thickness of the waxes. The rate of degradation of waxes appears to be cultivar dependent. After six months of storage, the ozonation process prevented decay of 'Iedzenu', 'Auksis' and 'Belorusskoje Malinovoje' apple cultivars, but it accelerated damage in cultivar 'Gita' apple samples. Moreover, a positive impact of ozone during long-term storage was also found for flesh firmness of 'Iedzenu' apples subjected to $\mathrm{O}_{3}$ exposure at concentrations of 0.8 . ppm and $3.0 \mathrm{ppm}$. In turn, no significant differences were found for other cultivars of apples between ozonation and cold storage (control). The data obtained show that after six months of storage, 'Iedzenu' cultivar samples, stored both under normal atmosphere conditions and treated with ozone at a concentration of $0.8 \mathrm{ppm}$ (IE_C and IE_0.8 ppm), were characterized as fruits with the most pronounced aroma, acidity, sweetness, taste and better maturity stage. Furthermore, apple samples: BM_C; BM_0.8 ppm; BM_3.0 ppm; AU_C; AU_0.8 ppm have been highlighted as samples with pronounced juiciness and appearance. In general, the results indicate that conventional cold storage with a combination of ozone treatments could be used as a novel technology that is capable of preserving both chemical and sensory quality of apples during longterm storage. However, the degree of effectiveness depends both on the cultivar and on the concentration of ozone.

\section{DECLARATION OF CONFLICTING INTERESTS}

The author(s) declared no potential conflicts of interest with respect to the research, authorship, and/or publication of this article.

\section{FUNDING}

The author(s) disclosed receipt of the following financial support for the research, authorship, and/or publication of this article: This research commissioned by Agricultural services co-operative society 'AUGழ̧ NAMS' has been conducted within framework 'The research of fruit storage technologies' funded by State program 'Competence Centre for Food in Latvia'.

\section{REFERENCES}

Alegria C, Pinheiro J, Goncalves EM, Fernandes I, Moldao M and Abreu M. (2009). Quality attributes of shredded carrot (Daucus carota L. cv. Nantes) as affected by alternative decontamination processes to chlorine. Innovative Food Science and Emerging Technologies 10(1): 61-69.

Alencar ER, Faroni LRA, Pinto MS, Costa AR and Carvalho AF. (2014). Effectiveness of ozone on 
postharvest conservation of pear (Pyrus communis L.). Journal of Food Processing and Technology 5: 1-5.

Barboni T, Cannac M and Chiaramonti N. (2010). Effect of cold storage and ozone treatment on physicochemical parameters, soluble sugars and organic acids in. Actinidia deliciosa. Food Chemistry 121(4): 946-951.

Biller E, Ekielski A and Zaremba R. (2007). Dynamics of colour changes in different apple varieties during drying. Polish Journal of Food and Nutrition Sciences 57(2A): 35-39.

Billiard F. (1999). Fruit cold storage: Techniques and equipment. Acta Horticulturae 485: 61-70.

Brand-Williams W, Cuvelier ME and Berset C. (1995). Use of free radical method to evaluate antioxidant activity. Lebensmittel-Wissenschaft and Technologie 28(1): 25-30.

Charles MT, Benhamou N and Arul J. (2008). Physiological basis of UV-C induced resistance to Botrytis cinerea in tomato fruit. III. Ultrastructural modifications and their impact on fungal colonization. Postharvest Biology and Technology 47(1): 27-40.

Conforti FD and Totty JA. (2007). Effect of three lipid/ hydrocolloid coatings on shelf life stability of Golden Delicious apples. International Journal of Food Science and Technology 42(9): 1101-1106.

FAOSTAT Food and Agriculture Organization of the United Nations Statistics Division. (WWW Document). Production crops summary, Available at: http://faostat3. fao.org/compare/E (2013, accessed 4 October 2016).

Forney CF. (2003). Postharvest response of horticultural products to ozone. In: Hodges DM (ed.) Postharvest Oxidative Stress in Horticultural Crops. New York: Food Products Press, pp. 13-54.

Forney CF, Song J, Fan LH, Hildebrand PD and Jordan MA. (2003). Ozone and 1-methylcyclopropene alter the postharvest quality of broccoli. Journal of the American Society for Horticultural Science 128(3): 403-408.

Greene DW, Krupa J and Autio W. (2014). Factors influencing preharvest drop of apples. Acta Horticiculturae 1042: 231-236.

Harding PR. (1968). Effect of ozone on Penicillium mold decay and sporulation. Plant Disease Report 52: 245-247.

Heleno FF, Queiroz MELR, Neves AA, Faroni LRA, Sousab FA and Oliveira AF. (2015). Ozone treatment for the removal of residual chlorothalonil and effects on the quality of table grapes. Journal of the Brazilian Chemical Society 26(4): 687-694.

Horvath M, Bilitzky L and Huttner J. (1985). Ozone. Amsterdam: Elsevier, pp. 68-74.

Jin L, Xiaoyu W, Honglin Y, Zonggan Y, Jiaxun W and Yaguang L. (1989). Influence of discharge products on post-harvest physiology of fruit. In: Proceedings of the 6th International Symposium on High Voltage Engineering, New Orleans, LA, 28 August to 1 September 1989, pp.1-4.

Juhnevica K, Krasnova I, Skudra G and Aboltins A. (2013). The assessment of apple shelf life after storage at modified atmosphere. Acta Horticulturae 981: 599-605.

Juhņeviča-Radenkova K, Radenkovs V and Segliņa D. (2016). Influence of 1-MCP treatment and storage conditions on the development of microorganisms on the surface of apples grown in Latvia. ZemdirbysteAgriculture 103(2): 215-220.

Kim JG, Yousef AE and Dave S. (1999). Application of ozone for enhancing the microbiological safety and quality of foods: A review. Journal of Food Protection 62(9): 1071-1078.

Kochar TK. (2015). The effects of ozone on compounds in epicuticular waxes in plant leaves, 2015 Undergraduate honours thesis, University of Redlands. Available at: http://inspire.redlands.edu/cas_honors/95 (accessed 1 October 2016).

Laurienzo P, Cammarotaa G, Stasioa MD, Gentileb G, Laurinoa C and Volpe MG. (2013). Microstructure and olfactory quality of apples de-hydrated by innovative technologies. Journal of Food Engineering 116(3): 689-694.

Liew CL and Prange RK. (1994). Effect of ozone and storage temperature on postharvest diseases and physiology of carrots (Daucus carota L.). Journal of the American Society for Horticultural Science 119(3): 563-567.

Liu C, Ma T, Hu W, Tian M and Sun L. (2016). Effects of aqueous ozone treatments on microbial load reduction and shelf life extension of fresh-cut apple. International Journal of Food Science and Technology 51(5): 1099-1109.

McCluskey JJ, Mittelhammer RC, Marin AB and Wright KS. (2007). Effect of quality characteristics on consumers' willingness to pay for Gala apples. Canadian Journal of Agricultural Economics 55(2): 217-231.

Miller FA, Silva CLM and Brandão TRS. (2013). A review on ozone-based treatments for fruit and vegetables preservation. Food Engineering Reviews 5(2): 77-106.

Næs T, Brockhoff P and Tomic O. (2010). Statistics for Sensory and Consumer Science. New York: Wiley Science, p. 294.

Paaver U, Matto V and Raal A. (2010). Total tannin content in distinct Quercus robur L. galls. Journal of Medical Plants Research 4(8): 702-705.

Palou L, Crisosto $\mathrm{CH}$, Smilanick JL, Adaskaveg JE and Zoffoli JP. (2002). Effects of continuous $0.3 \mathrm{ppm}$ ozone exposure on decay development and physiological responses of peaches and table grapes in cold storage. Postharvest Biology and Technology 24(1): 39-48.

Palou L, Smilanick JL, Crisosto $\mathrm{CH}$, Mansour M and Plaza P. (2003). Ozone gas penetration and control of the sporulation of Penicillium digitatum and Penicillium italicum within commercial packages of oranges during cold storage. Crop Protection 22(9): 1131-1134.

Patil S, Torres B, Tiwari BK, Wijngaard HH, Bourke P, Cullen PJ, et al. (2010). Safety and quality assessment during the ozonation of cloudy apple juice. Journal of Food Science 75(7): 437-443.

Percy KE, Manninen S, Häberle KH, Heerdt C, Werner H, Henderson GW, et al. (2009). Effect of 3 years' free-air exposure to elevated ozone on mature Norway spruce (Picea abies (L) Karst.) needle epicuticular wax physicochemical characteristics. Environmental Pollution 157(5): 1657-1665.

Pérez AG, Sanz C, Ríos JJ, Olías R and Olías JM. (1999). Effects of ozone treatment on postharvest strawberry quality. Journal of Agricultural and Food Chemistry 47(4): 1652-1656. 
Pinilla BL, Alvarez M and Godoy P. (1996). Effect of ionization in the control of gray mold on kiwi fruit. Revista Fruticola 17(2): 61-64.

Piqueras-Fiszman B, Ares G and Tomasco PV. (2015). An introduction to sensory evaluation techniques. In: Nollet MML and Toldra F (eds) Handbook of Food Analysis, 3rd ed. Broken Sound Parkway, NW: CRC Press, pp. 65-79.

Radenkovs V and Juhnevica-Radenkova K. (2018). Comparison of three storage techniques for post-harvest quality preservation of six commercially available cultivars of apple. International Journal of Fruit Science 18(3): 1-19.

Rodoni L, Casadei N, Concellón A, Chaves Alicia AR and Vicente AR. (2009). Effect of short-term ozone treatments on tomato (Solanum lycopersicum L.) fruit quality and cell wall degradation. Journal of Agricultural and Food Chemistry 58: 594-599.

Sanoner P, Guyot S, Marnet N, Molle D and Drilleau JF. (1999). Polyphenol profiles of French cider apple varieties (Malus domestica sp.). Journal of Agricultural and Food Chemistry 47(12): 4847-4853.

Sarig P, Zahvi T, Zutkhi Y, Yannai S, Lisker N and Ben-Arie R. (1996). Ozone for control of post-harvest decay of table grapes caused by. Rhizopus stolonifer. Physiological and Molecular Plant Pathology 48(6): 403-415.

Selma MV, Beltran D, Allende A, Chacon-Vera E and Gil MI. (2007). Elimination by ozone of Shigella sonnei in shredded lettuce and waterFood Microbiology 24(5): 492-499.

Singleton VL, Orthofer R and Lamuela-Raventos RM. (1999). Analysis of total phenols and other oxidation substrates and antioxidants by means of Folin-Ciocalteu reagent. Methods in Enzymology 299: 152-178.

Skog LJ and Chu CL. (2001). Effect of ozone on qualities of fruits and vegetables in cold storage. Canadian Journal of Plant Science 81(4): 773-778.
Smilanick JL. (2003). Use of ozone in storage and packing facilities. Washington tree fruit postharvest conference. Proceedings 2: 1-10.

Sung HJ, Song WJ, Kim KP, Ryu S and Kang DH. (2014). Combination effect of ozone and heat treatments for the inactivation of Escherichia coli O157: H7, Salmonella Typhimurium and Listeria monocytogenes in apple juice. International Journal of Food Microbiology 171: 147-153.

Tiwari BK, O'Donnell CP, Patras A, Brunton N and Cullen PJ. (2009). Anthocyanins and color degradation in ozonated grape juice. Food and Chemical Toxicology 4(11): 2824-2829.

Torres B, Tiwari BK, Patras A, Wijngaard HH, Brunton N, Cullen PJ, et al. (2011). Effect of ozone processing on the colour, rheological properties and phenolic content of apple juice. Food Chemistry 124(3): 721-726.

Tzortzakis N, Singleton I and Barnes J. (2007). Deployment of low level ozone-enrichment for the preservation of chilled fresh produce. Postharvest Biology and Technology 43(2): 261-270.

Venta MB, Broche SSC, Torres IF, Perez MG, Lorenzo EV, Rodriguez YR, et al. (2010). Ozone application for postharvest disinfection of tomatoes. Ozone: Science and Engineering 32(5): 361-371.

United State Food and Drug Organization (2018). Secondary direct food additives permitted in food for human consumption. Federal Regulation, Section 173.368, Title 21(3), Ref. 21CFR173.368.

Veravrbeke EA, Verboven P, Oostveldt P and Nicolai BM. (2003). Predication of moisture loss across the cuticle of apple (Malus sylvestris supsp. Mitis (Wallr.) during storage: Part 2. Model simulations and practical applications. Postharvest Biology and Technology 30(1): 89-97.

Yaseen T, Ricelli A, Turan B, Albanese P and D'Onghia AN. (2015). Ozone for post-harvest treatment of apple fruits. Phytopathologia Mediterranea 54(1): 94-103. 